\title{
Synthesis and Characterization of $12 \mathrm{CaO} \cdot 7 \mathrm{Al}_{2} \mathrm{O}_{3}$ Slags: The Effects of Impurities and Atmospheres on the Phase Relations
}

\author{
FABIAN IMANASA AZOF, KAI TANG, JINGLIN YOU, and JAFAR SAFARIAN
}

Synthesis of crystalline slags of $12 \mathrm{CaO} \cdot 7 \mathrm{Al}_{2} \mathrm{O}_{3}$ phase from the corresponding melt compositions in different atmospheric conditions and different purities is investigated. Observations using a thermogravimetry coupled with differential thermal analysis showed that the dehydration of a zeolitic $12 \mathrm{CaO} \cdot 7 \mathrm{Al}_{2} \mathrm{O}_{3}$ phase occur at $770{ }^{\circ} \mathrm{C}$ to $1390{ }^{\circ} \mathrm{C}$ before it congruently melts at $1450{ }^{\circ} \mathrm{C}$. The X-ray diffraction pattern of the slag showed that a single $12 \mathrm{CaO} \cdot 7 \mathrm{Al}_{2} \mathrm{O}_{3}$ phase is produced from a mixture, which has small $\mathrm{SiO}_{2}$ impurity with a 49:51 mass ratio of $\mathrm{CaO}$ to $\mathrm{Al}_{2} \mathrm{O}_{3}$. A scanning electron microscope and electron probe micro-analyzer showed that a minor $\mathrm{Ca}-\mathrm{Al}-\mathrm{Si}$-O-containing phase is in equilibrium with a grain-less $12 \mathrm{CaO} \cdot 7 \mathrm{Al}_{2} \mathrm{O}_{3}$ phase. Moreover, $12 \mathrm{CaO} \cdot 7 \mathrm{Al}_{2} \mathrm{O}_{3}$ is unstable at room temperature when the high-purity molten slag is solidified under oxidizing conditions contained in an alumina crucible. On the other hand, a high-temperature in-situ Raman spectroscopy of a slag that was made of a higher purity $\mathrm{CaO}-\mathrm{Al}_{2} \mathrm{O}_{3}$ mixture showed that $5 \mathrm{CaO} \cdot 3 \mathrm{Al}_{2} \mathrm{O}_{3}$ phase is an unstable/intermediate phase in the the $\mathrm{CaO}-\mathrm{Al}_{2} \mathrm{O}_{3}$ system, which is decomposed to $12 \mathrm{CaO} \cdot 7 \mathrm{Al}_{2} \mathrm{O}_{3}$ above $1100{ }^{\circ} \mathrm{C}$ upon heating in oxidizing conditions. It was found that $5 \mathrm{CaO} \cdot 3 \mathrm{Al}_{2} \mathrm{O}_{3}$ is present at room temperature when the $12 \mathrm{CaO} \cdot 7 \mathrm{Al}_{2} \mathrm{O}_{3}$ dissociates to a mixture of $5 \mathrm{CaO} \cdot 3 \mathrm{Al}_{2} \mathrm{O}_{3}, 3 \mathrm{CaO} \cdot \mathrm{Al}_{2} \mathrm{O}_{3}$, and $\mathrm{CaO} \cdot \mathrm{Al}_{2} \mathrm{O}_{3}$ phases during the cooling of the slag at $1180{ }^{\circ} \mathrm{C} \pm 20^{\circ} \mathrm{C}$ in reducing atmosphere. It is proposed that low concentrations of $\mathrm{Si}$ stabilize $12 \mathrm{CaO} \cdot 7 \mathrm{Al}_{2} \mathrm{O}_{3}$ (mayenite), in which $\mathrm{Si}$ is a solid solution in its lattice, which is named Si-mayenite. Regarding the calculated $\mathrm{CaO}-\mathrm{Al}_{2} \mathrm{O}_{3}-\mathrm{SiO}_{2}$ diagram in this study, this phase may contain a maximum of 4.7 wt pet $\mathrm{SiO}_{2}$, which depends on the total $\mathrm{SiO}_{2}$ in the system and the $\mathrm{Ca} / \mathrm{Al}$ ratio.

https://doi.org/10.1007/s11663-020-01969-8

(c) The Author(s) 2020

\section{INTRODUCTION}

IN 1909, the binary $\mathrm{CaO}-\mathrm{Al}_{2} \mathrm{O}_{3}$ phase diagram was initially reported by Shepherd and Wright. ${ }^{[1]}$ In addition to the pure $\mathrm{CaO}$ and $\mathrm{Al}_{2} \mathrm{O}_{3}$ phases, they observed four compounds in a range of 15 to 70 wt pct $\mathrm{Al}_{2} \mathrm{O}_{3}$, which were $\mathrm{CaO} \cdot \mathrm{Al}_{2} \mathrm{O}_{3}$ (denoted by $\mathrm{CA}$ ), $5 \mathrm{CaO} \cdot 3 \mathrm{Al}_{2} \mathrm{O}_{3}$ (denoted by $\mathrm{C}_{5} \mathrm{~A}_{3}$ ), $3 \mathrm{CaO} \cdot \mathrm{Al}_{2} \mathrm{O}_{3}$ (denoted by $\mathrm{C}_{3} \mathrm{~A}$ ), and an unstable form of both $3 \mathrm{CaO} \cdot 5 \mathrm{Al}_{2} \mathrm{O}_{3}$ (denoted by $\mathrm{C}_{3} \mathrm{~A}_{5}$ ) and $\mathrm{C}_{5} \mathrm{~A}_{3}$. Also, in 1911, they published a preliminary report on the ternary $\mathrm{CaO}-\mathrm{Al}_{2} \mathrm{O}_{3}-\mathrm{SiO}_{2}$ system, ${ }^{[2]}$ which

FABIAN IMANASA AZOF and JAFAR SAFARIAN are with the Norwegian University of Science and Technology (NTNU), Department of Materials Science and Engineering, 7491 Trondheim, Norway. Contact e-mail: fabian.i.azof@ntnu.no KAI TANG is with the SINTEF Industry, 7465 Trondheim, Norway. JINGLIN YOU is with the State Key Laboratory of Advanced Special Steel and Shanghai Key Laboratory of Advanced Ferrometallurgy, School of Materials Science and Engineering, Shanghai University, Shanghai200072, China.

Manuscript submitted December 6, 2019.

Article published online October 9, 2020. was of great importance on a study of the constitution of Portland cement clinker. Later on, Rankin and Wright ${ }^{[3]}$ in 1915 documented the ternary $\mathrm{CaO}-\mathrm{Al}_{2} \mathrm{O}_{3}$ $\mathrm{SiO}_{2}$ phase diagram, which was an updated version of the preliminary report. They had stated that $\mathrm{C}_{5} \mathrm{~A}_{3}$ formation occurred in two forms, a stable and an unstable monotropic form. The stable form melts at $1455^{\circ} \mathrm{C} \pm 5^{\circ} \mathrm{C}$ and has two eutectic mixtures with $\mathrm{C}_{3} \mathrm{~A}$ and CA phases. On the other hand, the unstable form has neither a definite melting point nor any range of temperatures regarding its stability.

It was not until 1936 that Büssem and Eitel ${ }^{[4]}$ showed that the $\mathrm{CaO}: \mathrm{Al}_{2} \mathrm{O}_{3}$ ratio of the synthesized stable $\mathrm{C}_{5} \mathrm{~A}_{3}$ phase from Rankin and Wright's study was 12:7 rather than 5:3, in which they suggested the chemical compound was $12 \mathrm{CaO} \cdot 7 \mathrm{Al}_{2} \mathrm{O}_{3}$ (denoted by $\mathrm{C}_{12} \mathrm{~A}_{7}$ ). Regarding this phase, Nurse et al. ${ }^{[5,6]}$ found that at elevated temperatures, $\mathrm{C}_{12} \mathrm{~A}_{7}$ is unstable in anhydrous or moistfree $\mathrm{CaO}-\mathrm{Al}_{2} \mathrm{O}_{3}$ systems. It is in equilibrium with $\mathrm{H}_{2} \mathrm{O}$ above $950{ }^{\circ} \mathrm{C}$ and forms $\mathrm{Ca}_{12} \mathrm{Al}_{14} \mathrm{O}_{32}(\mathrm{OH})_{2}$ when is fully saturated; water is present as hydroxyl ions in the crystal structure. The observation was in agreement with Roy and Roy, ${ }^{[7]}$ who had previously reported the 
zeolitic behavior of the phase. The zeolitic behavior means that the phase absorbs and desorbs water as a function of temperature (with $\mathrm{pH}_{2} \mathrm{O}$ fixed). They found that $\mathrm{C}_{12} \mathrm{~A}_{7}$ could absorb water vapor even at $1000{ }^{\circ} \mathrm{C}$ at a $p \mathrm{H}_{2} \mathrm{O}$ of $1.6 \times 10^{-3}$ atm. In a similar conclusion, Imlach et al. ${ }^{[8]}$ claimed that the $\mathrm{C}_{12} \mathrm{~A}_{7}$ phase is stable at high temperatures as it absorbs excess of oxygen from an oxidizing atmosphere, even where $p \mathrm{O}_{2}$ is as low as $10^{-8} \mathrm{~atm}$. In other words, according to them, the phase is very efficient at extracting oxygen from the surrounding atmosphere.

According to Büssem and Eitel, ${ }^{[4]}$ the $\mathrm{C}_{12} \mathrm{~A}_{7}$ phase in its anhydrous form has the following physical properties: $a=11.982 \AA, V=1720.24 \AA^{3}$, and bulk density $=2.85$ $\times 10^{3} \mathrm{~kg} \mathrm{~m}^{-3}$, in the cubic I-43d (220) space group. In 1962, Jeevaratnam et al. ${ }^{[9]}$ used a petrographic microscope to investigate the $\mathrm{C}_{12} \mathrm{~A}_{7}$ crystal structure and showed results that were in agreement with the work of Büssem and Eitel as well. As mentioned earlier, Rankin and Wright ${ }^{[3]}$ claimed that $\mathrm{C}_{12} \mathrm{~A}_{7}$ melts at $1455^{\circ} \mathrm{C} \pm 5^{\circ} \mathrm{C}$, whereas Nurse et al. ${ }^{[6]}$ used a high-temperature microscope and proposed that $\mathrm{C}_{12} \mathrm{~A}_{7}$ crystals are seen to melt at $1392{ }^{\circ} \mathrm{C} \pm 3{ }^{\circ} \mathrm{C}$. Later, Hallstedt ${ }^{[10]}$ optimized the thermodynamic data of $\mathrm{C}_{12} \mathrm{~A}_{7}$ phase using CALPHAD, which stands for the Calculation of Phase Diagram technique, and reported that the phase melts congruently at $1449{ }^{\circ} \mathrm{C}$ and has a eutectic with other phases $\mathrm{C}_{3} \mathrm{~A}$ and $\mathrm{CA}$ on each side. Thermodynamic properties of the $\mathrm{C}_{12} \mathrm{~A}_{7}$ phase have been evaluated based on the phase equilibrium information given by Rankin ${ }^{[3]}$ and Nurse et al. ${ }^{[6]}$ An updated thermodynamic description of the $\mathrm{CaO}-\mathrm{Al}_{2} \mathrm{O}_{3}-\mathrm{SiO}_{2}$ system has been established using FactSage ${ }^{\mathrm{TM}}$, a thermochemical simulation software. A part of the $\mathrm{CaO}-\mathrm{Al}_{2} \mathrm{O}_{3}$ phase diagram that includes the $\mathrm{C}_{12} \mathrm{~A}_{7}$ phase is calculated and shown in Figure 1. It is worth noting that the presented phase diagrams for this binary system in the literature ${ }^{[1-13]}$ may not show the $\mathrm{C}_{12} \mathrm{~A}_{7}$ phase, assuming that it is not a stable phase.

A stoichiometric compound of $\mathrm{C}_{12} \mathrm{~A}_{7}$ has a unit cell that consists of $\left(\mathrm{Ca}_{24} \mathrm{Al}_{28} \mathrm{O}_{64}\right)^{4+} \cdot 2 \mathrm{O}^{2-}$, in which the first part is a lattice framework with 12 subnanocages and the latter is called an extra framework oxide ions that are randomly distributed in the cages. ${ }^{[14]}$ The stability of anhydrous $\mathrm{C}_{12} \mathrm{~A}_{7}$ has been investigated intensively as the phase exhibits excellent properties as inorganic electrides. ${ }^{[15-18]}$ Electrides are regarded as ionic compounds, where electrons act as anions and can be utilized in various fields, such as catalysis, batteries, reducing agents, and electronic and optoelectronic devices. ${ }^{[17,19]}$ Furthermore, studies have been conducted to investigate the stability and properties of synthetic doped $\mathrm{C}_{12} \mathrm{~A}_{7}$ compounds with a cationic dopant, i.e., $\mathrm{Si}^{[20]} \mathrm{Fe},{ }^{[21]} \mathrm{Mg},{ }^{[22]} \mathrm{Cu},{ }^{[23]}$ etc., where the dopant substitutes the cation site of the $\left(\mathrm{Ca}_{24} \mathrm{Al}_{28} \mathrm{O}_{64}\right)^{4+}$ framework based on its ionic radii.

In 2017, the European Commission under the Horizon 2020 program launched a project that is named ENSUREAL (www.ensureal.com). The project works on a sustainable alumina recovery from bauxite that is based on a smelting-reduction process that produces

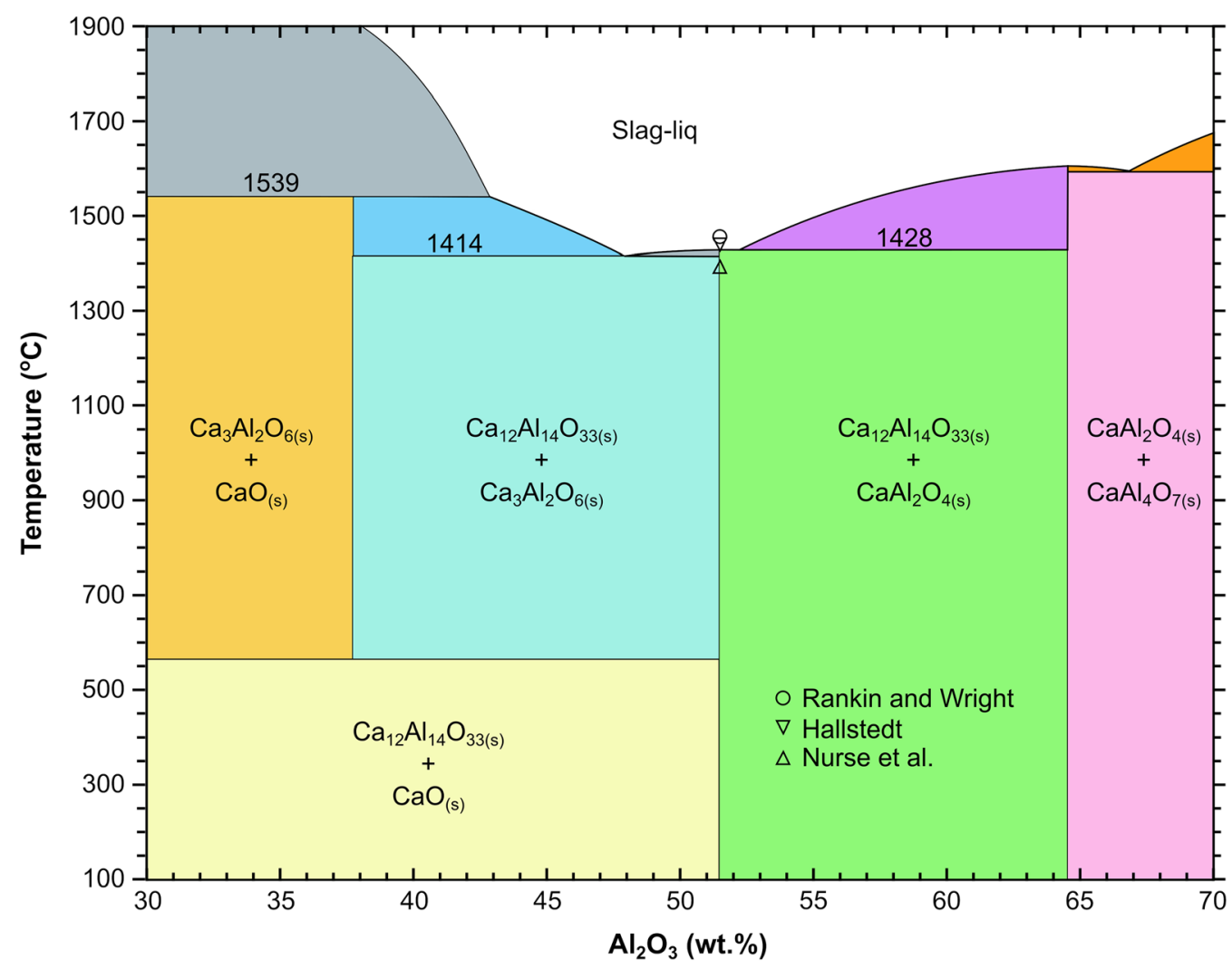

Fig. 1-A part of the $\mathrm{CaO}-\mathrm{Al}_{2} \mathrm{O}_{3}$ phase diagram as constructed using FactSage ${ }^{\mathrm{TM}}$, which includes the $\mathrm{C}_{12} \mathrm{~A}_{7}$ phase and its melting point according to Hallstedt, ${ }^{[10]}$ Nurse et al..${ }^{[5]}$ and Rankin and Wright. ${ }^{[3]}$ 
Table I. Target Slag Composition That Is Classified by Different Raw Material Purities, Crucible Types, and Melting

\begin{tabular}{|c|c|c|c|c|c|c|}
\hline \multirow[b]{2}{*}{ Sample Name } & \multicolumn{2}{|c|}{ Composition } & \multirow[b]{2}{*}{$\begin{array}{l}\text { Raw Material } \\
\text { Purity }\end{array}$} & \multirow[b]{2}{*}{ Crucible Type } & \multirow[b]{2}{*}{$\begin{array}{l}\text { Use a Graphite or } \\
\text { Alumina lid }\end{array}$} & \multirow[b]{2}{*}{$\begin{array}{l}\text { Melting Atmospheric } \\
\text { Condition }\end{array}$} \\
\hline & $\begin{array}{c}\mathrm{CaO} \\
(\mathrm{Wt} \mathrm{Pct})\end{array}$ & $\begin{array}{l}\mathrm{Al}_{2} \mathrm{O}_{3} \text { (Weight } \\
\text { Percent })\end{array}$ & & & & \\
\hline Slag 3(a) & 49 & 51 & less pure & graphite & no & reduction with $\mathrm{O}_{2(\mathrm{~g})}$ present \\
\hline Slag 3(b) & 49 & 51 & pure & graphite & no & reduction with $\mathrm{O}_{2(\mathrm{~g})}$ present \\
\hline Slag 3(c) & 49 & 51 & pure & graphite & yes, graphite lid & reduction \\
\hline Slag 3(d) & 49 & 51 & pure & alumina & yes, alumina lid & oxidation \\
\hline Slag 3(a)-remelted & 49 & 51 & less pure & graphite & yes, graphite lid & reduction \\
\hline Slag 4(a) & 54 & 46 & less pure & graphite & no & reduction with $\mathrm{O}_{2(\mathrm{~g})}$ present \\
\hline Slag 4(b) & 54 & 46 & pure & graphite & no & reduction with $\mathrm{O}_{2(\mathrm{~g})}$ present \\
\hline Slag 4(c) & 54 & 46 & pure & graphite & yes, graphite lid & reduction \\
\hline Slag 4(d) & 54 & 46 & pure & alumina & yes, alumina lid & oxidation \\
\hline
\end{tabular}

calcium-aluminate slags that can be further leached in the $\mathrm{Na}_{2} \mathrm{CO}_{3}$ solution for alumina recovery. ${ }^{[24-32]}$ One of the known leachable and favorable phases in the slags is the $\mathrm{C}_{12} \mathrm{~A}_{7}$ phase, which has been reported in several studies. ${ }^{[24,33-35]}$ However, the formation of the $\mathrm{C}_{12} \mathrm{~A}_{7}$ phase in slags produced from the smelting reduction of bauxite, and its behavior under different conditions is still unclear. ${ }^{[27]}$ Therefore, it is necessary to study the stability of $\mathrm{C}_{12} \mathrm{~A}_{7}$ as well as other known metastable phase, $\mathrm{C}_{5} \mathrm{~A}_{3}$, that are produced from calcium-aluminate melts at different conditions.

\section{EXPERIMENTAL PROCEDURE}

\section{A. Slagmaking}

The $\mathrm{C}_{12} \mathrm{~A}_{7}$ phase consists of 12 moles $\mathrm{CaO}$ and 7 moles $\mathrm{Al}_{2} \mathrm{O}_{3}$, which is equivalent to a mass ratio of $49: 51$ of $\mathrm{CaO}$ to $\mathrm{Al}_{2} \mathrm{O}_{3}(\mathrm{C} / \mathrm{A})$. In the current study, four slags (denoted as slags 3(a) to (d)) were made in the mass ratio of 49:51 C/A, and four other slags (denoted as slags 4(a) to (d)) were in the ratio 54:46. The slag numbers here are based on the labeled slags in our previously published work and are kept in this research to be more convenient for the readers. ${ }^{[24]}$ The slags were made from different raw material purity and atmospheric conditions. The compositions of the $\mathrm{CaO}$ and $\mathrm{Al}_{2} \mathrm{O}_{3}$ powders used for the pure mixture are $99.9 \mathrm{wt}$ pct $\mathrm{CaO}$ and $99.95 \mathrm{wt}$ pct $\mathrm{Al}_{2} \mathrm{O}_{3}$, whereas the less pure mixtures were made from 96 wt pet $\mathrm{CaO}$ and the same 99.95 wt pct $\mathrm{Al}_{2} \mathrm{O}_{3}$. Table I shows the names, composition, and melting parameters of each sample. In addition to the eight different slags, slag 3(a) was re-melted in a reducing condition to see the stability of phases that were formed in its first treatment.

Mixtures of $\mathrm{CaO}$ and $\mathrm{Al}_{2} \mathrm{O}_{3}$ powders were appropriately prepared using a polyethylene-based mixing jar that contained ceramic balls. The weight of each mixture was $25 \mathrm{~g}$. The mixtures were poured into either a graphite or alumina crucible with about 30 and $50 \mathrm{~mm}$ inner diameter and height. In the melting of slags 3(c), 3(d), 4(c), 4(d), and re-melted 3(a), to reduce the oxygen interference and create either a reducing or oxidizing atmosphere, the top of the crucible was closed using a lid. On the other hand, the remaining slags were not smelted using the lid. The relatively small crucibles were then placed into a larger graphite crucible. The crucibles were heated by using a $75-\mathrm{kVA}$ open induction furnace slowly at the rate of $30{ }^{\circ} \mathrm{C} / \mathrm{min}$ until the temperature reached $1650{ }^{\circ} \mathrm{C}$. The temperature was kept for 30 minutes before it was subsequently cooled down in the furnace slowly. A hydrated phase of $\mathrm{CaO}$, which is $\mathrm{Ca}(\mathrm{OH})_{2}$, may exist when the $\mathrm{CaO}$ is exposed in a moisture-containing atmosphere. However, the dissociation of $\mathrm{Ca}(\mathrm{OH})_{2}$ takes place at around $525{ }^{\circ} \mathrm{C}$. In our experimental work, the working temperature is substantially higher than that temperature as mentioned above $\left(1650{ }^{\circ} \mathrm{C}\right)$. Therefore, any structural moisture is eliminated. The thermocouple used in the study was tungsten/rhenium (C-type), which was encapsulated by alumina and graphite insulation tubes. The schematic of the melting setup is shown in Figure 2.

The melting profile of the slag-making step is shown in Figure 3. On average, the heating rate from room temperature to $1000{ }^{\circ} \mathrm{C}$ and from $1000{ }^{\circ} \mathrm{C}$ to $1650{ }^{\circ} \mathrm{C}$ was 37.9 and $26.1{ }^{\circ} \mathrm{C} / \mathrm{min}$, respectively, whereas the cooling rate from 1650 to 1450,1450 to 1000,1000 to 600 , and 600 to room temperature were, respectively, $32.5,29.2,10.0$, and $1.1^{\circ} \mathrm{C} / \mathrm{min}$, on average.

\section{B. Characterization Techniques}

High-resolution imaging, energy dispersive spectroscopy (EDS) analysis, and X-ray element mapping of slags were carried out using a Hitachi SU6600 ${ }^{\mathrm{TM}}$ scanning electron microscope (SEM). We used a high-resolution electron probe micro-analyzer (EPMA) JXA-8500F $\mathrm{F}^{\mathrm{TM}}$, which was supported by wavelength dispersive spectroscopy (WDS), to get high accuracy on quantitative analysis of elements in selected phases of the slags. To obtain clear images from the SEM and EPMA instruments, a flat and relatively smooth surface of slag samples is necessary. First, the surface of the slag was ground using a Si-C abrasive paper $800(22 \mu \mathrm{m})$ and $1200(15 \mu \mathrm{m})$ grit. Second, it was polished using a 


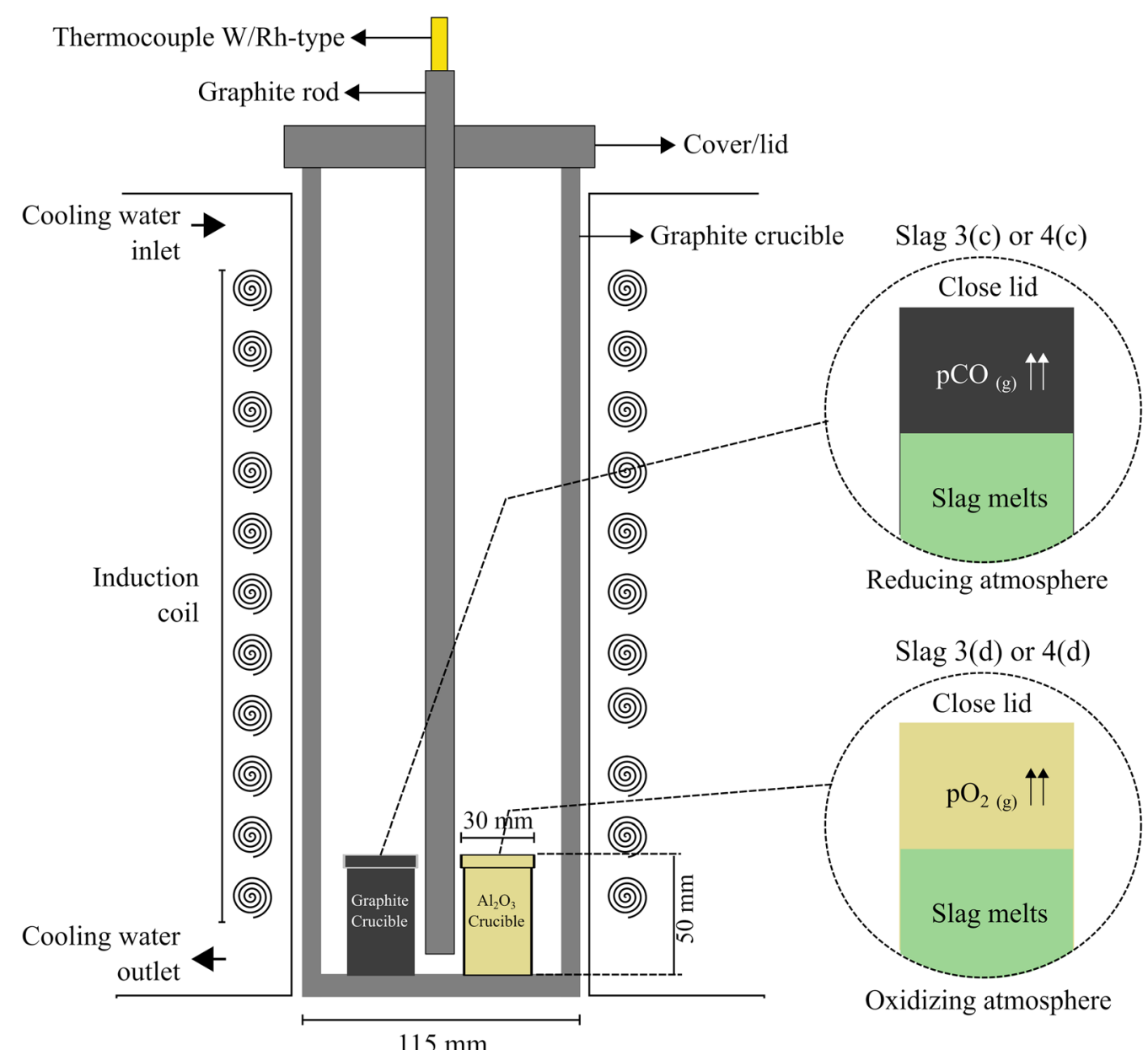

(a) A cross section view of the melting setup that shows arrangement of crucibles, thermocouple, and induction furnace

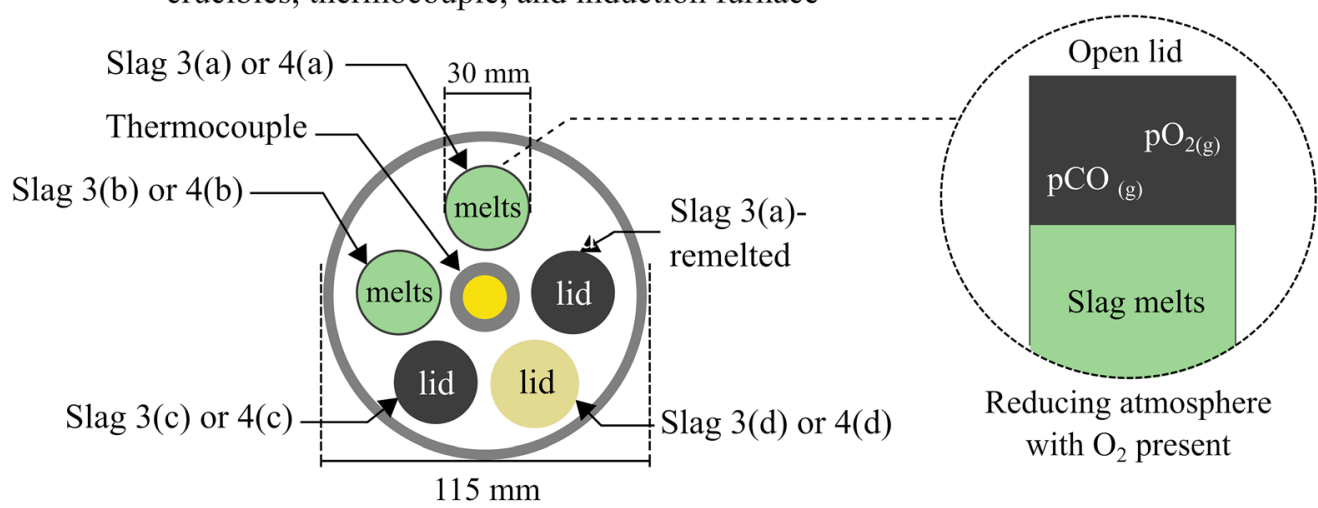

(b) A top view of the melting setup

Fig. 2-A schematic diagram of the melting setup with different crucibles and atmospheric conditions from $(a)$ cross-section and $(b)$ top views.

polyurethane-based pad as the polisher and an abrasive diamond water-based type as the polishing agent gradually from $9,6,3$, and $1 \mu \mathrm{m}$ particle size. The polished samples were cleaned by tap water and a cotton swab. Finally, alcohol was squirted on the sample surface to replace the water and provide better cleaning efficiency. The sample was dried in an oven for over a day.
Phase identification of the slags was undertaken with a Bruker D8 A25 DaVinci ${ }^{\mathrm{TM}}$ X-ray diffraction (XRD) machine with $\mathrm{CuK} \alpha$ radiation, between 10 and $75 \mathrm{deg}$ diffraction angle, $0.01 \mathrm{deg}$ step size, $6.0 \mathrm{~mm}$ slit width, and 2.5 deg for both the primary and secondary soller slit. The sample for XRD characterization was provided by pulverizing the slags using a Retsch RS-200 vibratory 
ring mill at $800 \mathrm{rpm}$ for 1 minutes. Additional grinding using an agate-based mortar and pestle also was performed to ensure the particle size was fine enough. The identification and qualitative phase analysis of the obtained XRD peaks were done by using DIFFRAC.EVA ${ }^{\mathrm{TM}}$, where the diffraction of the corresponding slags was then compared with the Powder Diffraction File $^{\mathrm{TM}}$ (PDF®) and Crystallography Open Database (COD). ${ }^{[36]}$

For thermal analysis, thermogravimetry (TG) and differential thermal analysis (DTA) NETZSCH STA 449 C $^{\text {TM }}$, combined with QMS 403C ${ }^{\text {TM }}$ mass spectrometry, was used. An alumina crucible was used and exposed in synthetic air, which flows at $30 \mathrm{~mL} / \mathrm{min}$ and was heated at a ramp of $10{ }^{\circ} \mathrm{C} / \mathrm{min}$ up to $1500{ }^{\circ} \mathrm{C}$. Thus, after 30 minutes it was cooled down to room temperature at $10{ }^{\circ} \mathrm{C} / \mathrm{min}$. The TG-DTA apparatus has a demoisturizer unit. Therefore, the moisture content of the gas should be quite low. Unfortunately, the moisture content was not measured. As a mass reference, an empty alumina crucible was used and exposed in the same condition as mentioned above before every TG-DTA experiment. Afterward, a $10 \mathrm{~g}$ sample of pulverized slags was weighed and added to the empty crucible. The instrument measured and recorded the

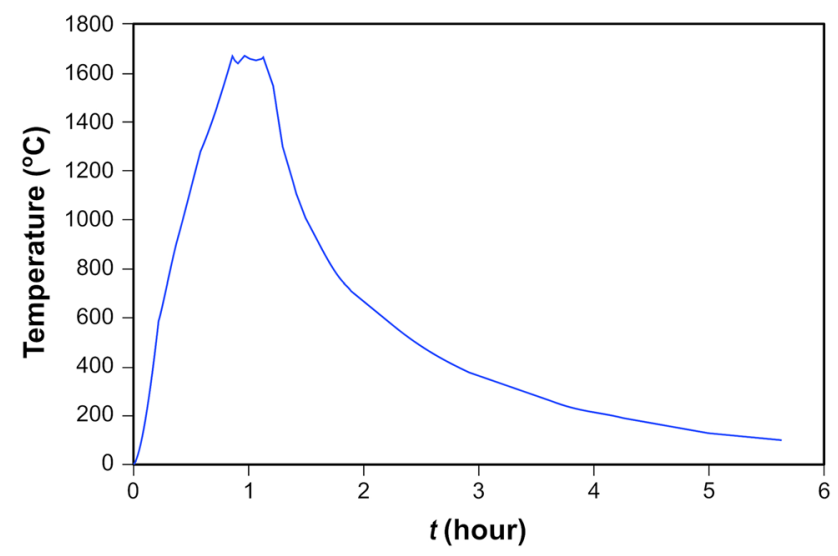

Fig. 3-Melting temperature $\left({ }^{\circ} \mathrm{C}\right.$ ) as a function of $t$ (hour) from the slag making experiment. mass loss and DTA curve $(\mu \mathrm{V} / \mathrm{mg})$ as a function of time and temperature. The result was then subtracted with the result of the previous run without the sample.

Furthermore, a Jobin Y'von LabRAM HR Evolution $^{\text {TM }}$ high-temperature Raman spectrometer was used to determine the Raman spectra of the slags. It uses a visible pulse laser with a wavelength of $532 \mathrm{~nm}$. The laser output power, slide width, and scanning wavenumber range are $100 \mathrm{~mW}, 200 \mu \mathrm{m}$, and 200 to $1200 \mathrm{~cm}^{-1}$, respectively. A platinum crucible with $5 \mathrm{~mm}$ diameter and $2 \mathrm{~mm}$ depth was used when experimenting with the measurement. The heating rate from room temperature to $1000{ }^{\circ} \mathrm{C}$ was $500{ }^{\circ} \mathrm{C} / \mathrm{min}$, in which the spectrum was measured after holding at $500{ }^{\circ} \mathrm{C}, 800{ }^{\circ} \mathrm{C}$, and $1000{ }^{\circ} \mathrm{C}$ for 10 minutes. Furthermore, from $1000{ }^{\circ} \mathrm{C}$ to $1485^{\circ} \mathrm{C}$, the heating rate was $200{ }^{\circ} \mathrm{C} / \mathrm{min}$, in which the spectrum was measured after 10 minutes at $1200{ }^{\circ} \mathrm{C}, 1300{ }^{\circ} \mathrm{C}$, $1400{ }^{\circ} \mathrm{C}, 1450{ }^{\circ} \mathrm{C}$, and $1485^{\circ} \mathrm{C}$. The measurements were carried out under ambient pressure.

\section{RESULTS}

\section{A. The Appearance of Slags}

After cooling down the slag samples to room temperature, we cut half of the crucible of slags 3(c), 3(d), 4(c), 4(d), and re-melted $\mathrm{C}_{12} \mathrm{~A}_{7}$ and took an image of the cross-section as shown in Figure 4. The colors of the slags from the reducing atmosphere are dark gray, while slags from the oxidizing atmosphere are dominant in white, and the slag from the re-melting of slag 3(a) at reducing atmosphere is dark green. The appearance result agrees with the literature ${ }^{[5,19]}$ as it is said that a slag containing $\mathrm{CA}$ and $\mathrm{C}_{3} \mathrm{~A}$ phase is likely to have gray color, whereas a slag that is produced from a melting process using a carbon crucible that contains $\mathrm{C}_{12} \mathrm{~A}_{7}$ phase has a dark green color.

\section{B. Phase Analysis}

The XRD patterns of slags 3(b), (c), and (d) are shown in Figure 5. The patterns indicate the effect of atmospheric conditions on the slag phases. The order of phases from the strongest to the weakest intensities on

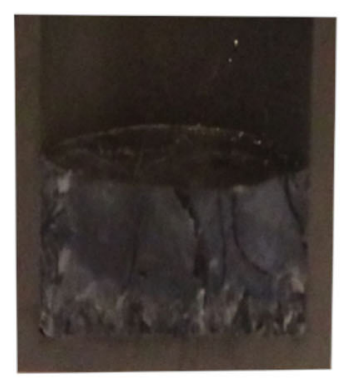

Slag 3(c) reducing atmosphere

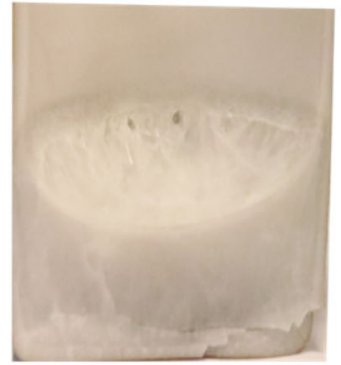

Slag 3(d) oxidizing atmosphere

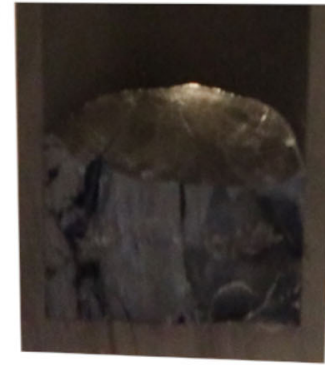

Slag 4(c) reducing atmosphere

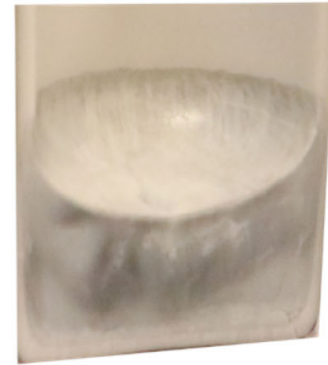

Slag 4(d) oxidizing atmosphere

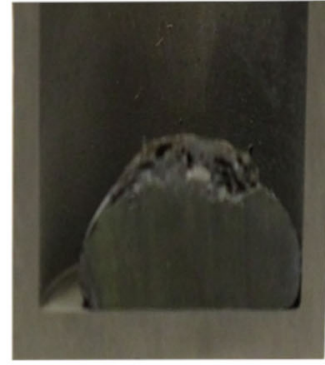

Remelting Slag 3(a) at reducing atmosphere

Fig. 4-A cross-section view of slags 3(c), 3(d), 4(c), 4(d), and the remelted slag 3(a). 


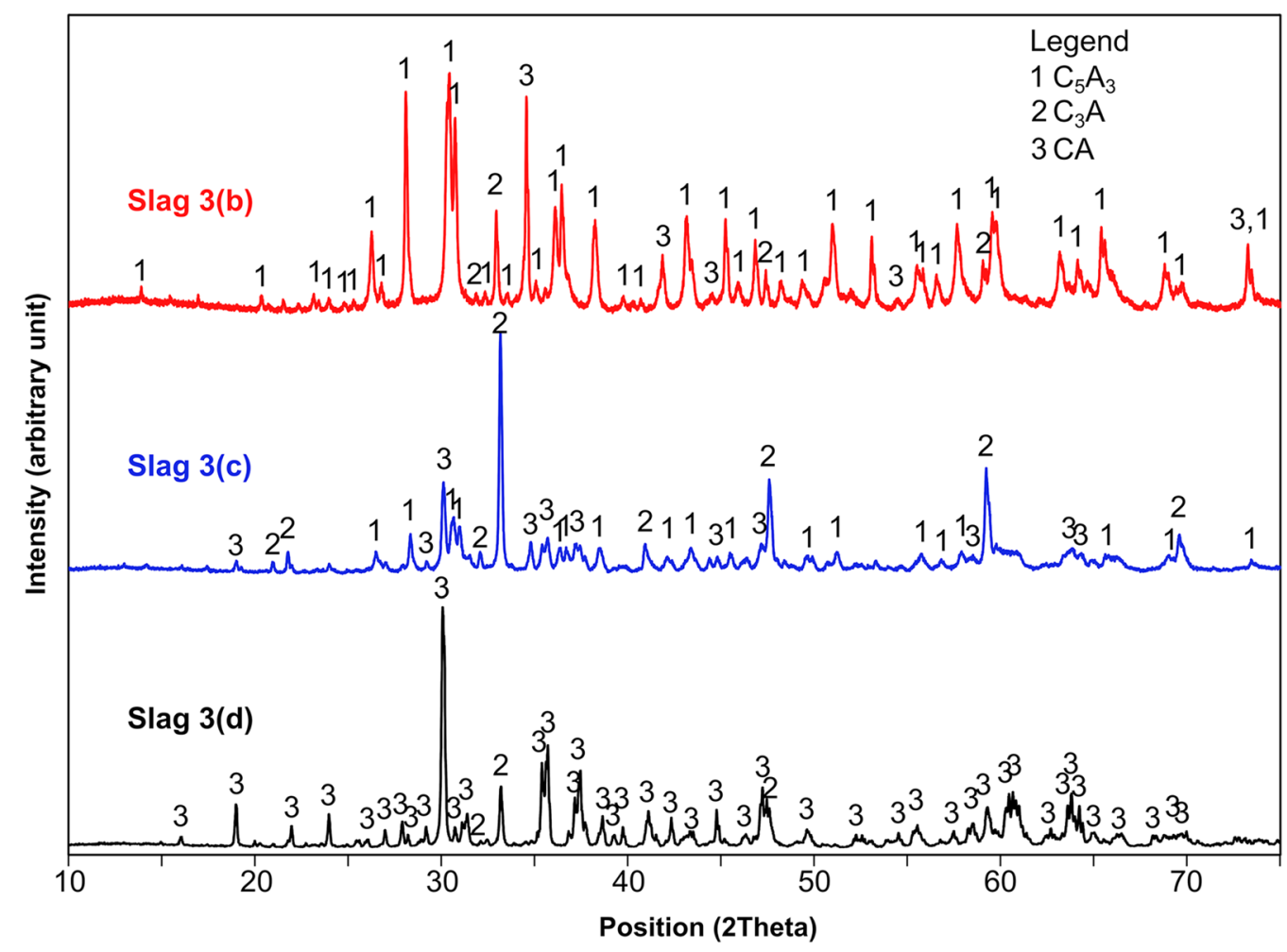

Fig. 5-XRD patterns of slags 3(b), (c), and (d), produced from pure mixtures in reducing with $\mathrm{O}_{2}$ presence, reducing, and oxidizing conditions, respectively.

slag 3(b) is $\mathrm{C}_{5} \mathrm{~A}_{3}, \mathrm{CA}$, and $\mathrm{C}_{3} \mathrm{~A}$. On slag 3(c), the order of phases is $\mathrm{C}_{3} \mathrm{~A}, \mathrm{CA}$, and $\mathrm{C}_{5} \mathrm{~A}_{3}$, while on slag $3(\mathrm{~d})$ the order is $\mathrm{CA}$ and $\mathrm{C}_{3} \mathrm{~A}$.

The XRD patterns of slags 3(a) and (b) are shown in Figure 6. The patterns show the comparison of the phases of the slags produced from different purities. The strongest peak observed on slag 3(a), which was produced from a less pure mixture, is the $\mathrm{C}_{12} \mathrm{~A}_{7}$ phase. On the other hand, as mentioned earlier, slag 3(b), which was produced from the highly pure mixture, consists of $\mathrm{C}_{5} \mathrm{~A}_{3}, \mathrm{C}_{3} \mathrm{~A}$, and $\mathrm{CA}$ phases.

XRD results of slag 3(a) and slag 3(a)-remelted at reducing conditions are compared in Figure 7 . The PDF database number 01-078-2975, which refers to the $\mathrm{C}_{12} \mathrm{~A}_{7}$ phase, is also included in the figure. As seen, the congruent $\mathrm{C}_{12} \mathrm{~A}_{7}$ phase is still stable at room temperature even after the slag 3(a) has been re-melted. There are weak peaks at 17.5, 26.5, and 32 degrees in both slag 3(a) and in re-melted slag 3(a) XRD patterns, in which later we find that the peak may belong to a Ca-Al-Si-O-containing phase on the slags.

The XRD patterns of slags 4(b), (c), and (d) are shown in Figure 8. The results show that under reducing conditions with $\mathrm{O}_{2}$ presence, $\mathrm{C}_{5} \mathrm{~A}_{3}$ and $\mathrm{C}_{3} \mathrm{~A}$ are the observable phases on slag 4 , which was produced from pure mixtures. Meanwhile, $\mathrm{C}_{5} \mathrm{~A}_{3}$ does not exist on slags 4(c) and (d), which are both reducing and oxidizing conditions. The existing phases on slags 4(c) and (d) are $\mathrm{C}_{3} \mathrm{~A}$ and $\mathrm{CA}$.
The effect of mixture purity on the phase equilibrium of slag 4 is shown in the XRD patterns in Figure 9. As seen, the slag that was produced from a less pure mixture has $\mathrm{C}_{12} \mathrm{~A}_{7}$ and $\mathrm{C}_{3} \mathrm{~A}$ in equilibrium at room temperature. Meanwhile, the slag that was produced from a pure mixture has $\mathrm{C}_{5} \mathrm{~A}_{3}$ and $\mathrm{C}_{3} \mathrm{~A}$ phase. Both slags 4(a) and (b) were exposed to reducing conditions with $\mathrm{O}_{2}$ presence during the melting treatment.

In summary, the phases of all of the slags that were identified with various diffraction database references are shown in Table II.

\section{Microstructural Analysis}

The x-ray mapping of elements performed for slags 3(a) and 3(b) as typical results is shown in Figures 10 and 11, respectively. As shown earlier from the XRD results, slag 3(a) consists of a single $\mathrm{C}_{12} \mathrm{~A}_{7}$ phase; meanwhile, slag 3(b) consists of $\mathrm{C}_{5} \mathrm{~A}_{3}, \mathrm{CA}$, and $\mathrm{C}_{3} \mathrm{~A}$ phases. The result of $\mathrm{X}$-ray mapping elements for slag 3(a) shows that in addition to $\mathrm{C}_{12} \mathrm{~A}_{7}$, the slag also has another phase that is visually distinct because of its irregular shape and brighter contrast compared to the matrix. The phase has a higher concentration of calcium and silicon compared to the matrix (hereafter named the Ca-Al-Si-O-containing phase).

Furthermore, the X-ray mapping of elements in slag 3(b) in Figure 11 shows that two phases exist in the slag: a matrix and a bright phase. It seems that the bright phase, which is present between the matrix boundaries, 


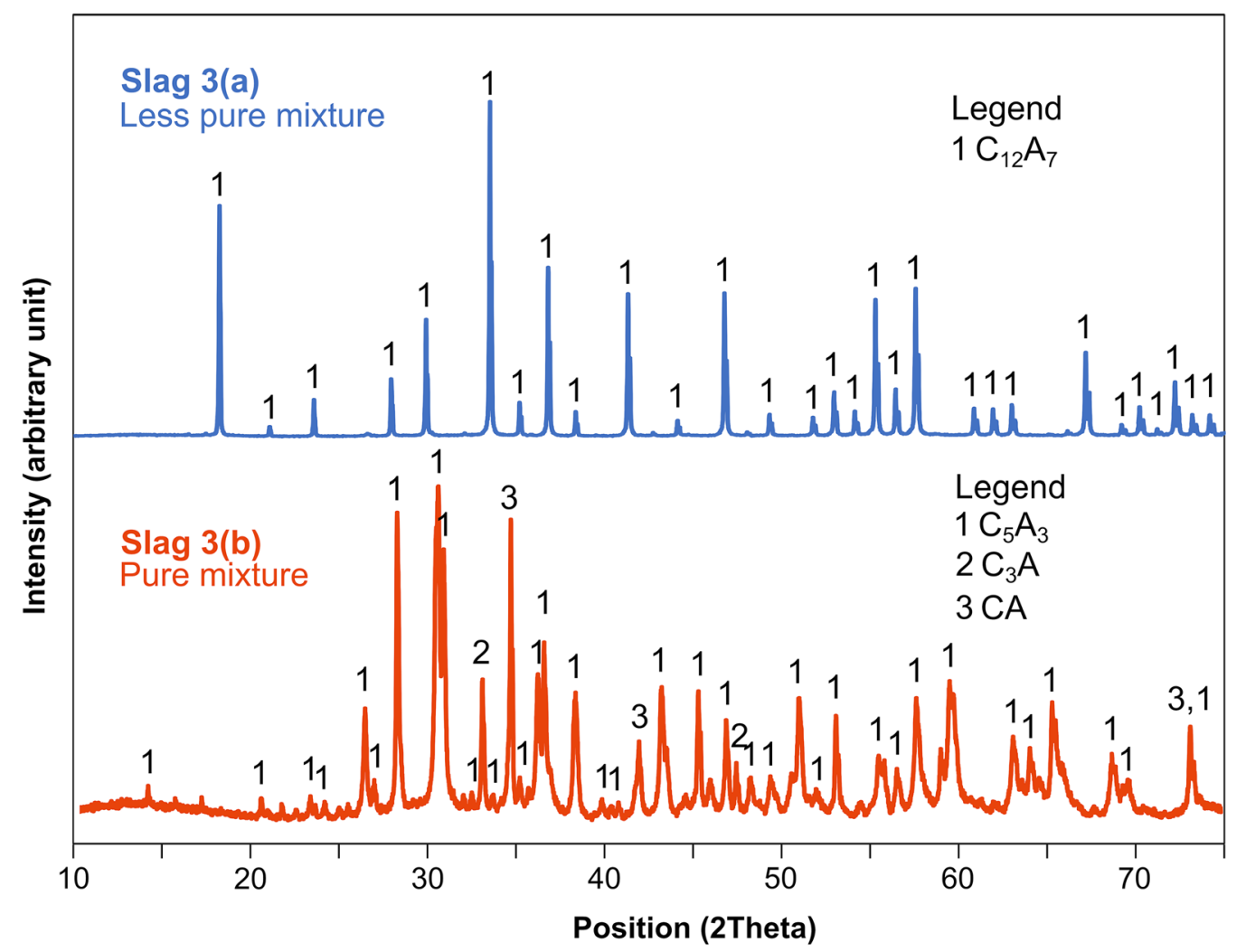

Fig. 6-XRD patterns of slags 3(a) and (b).

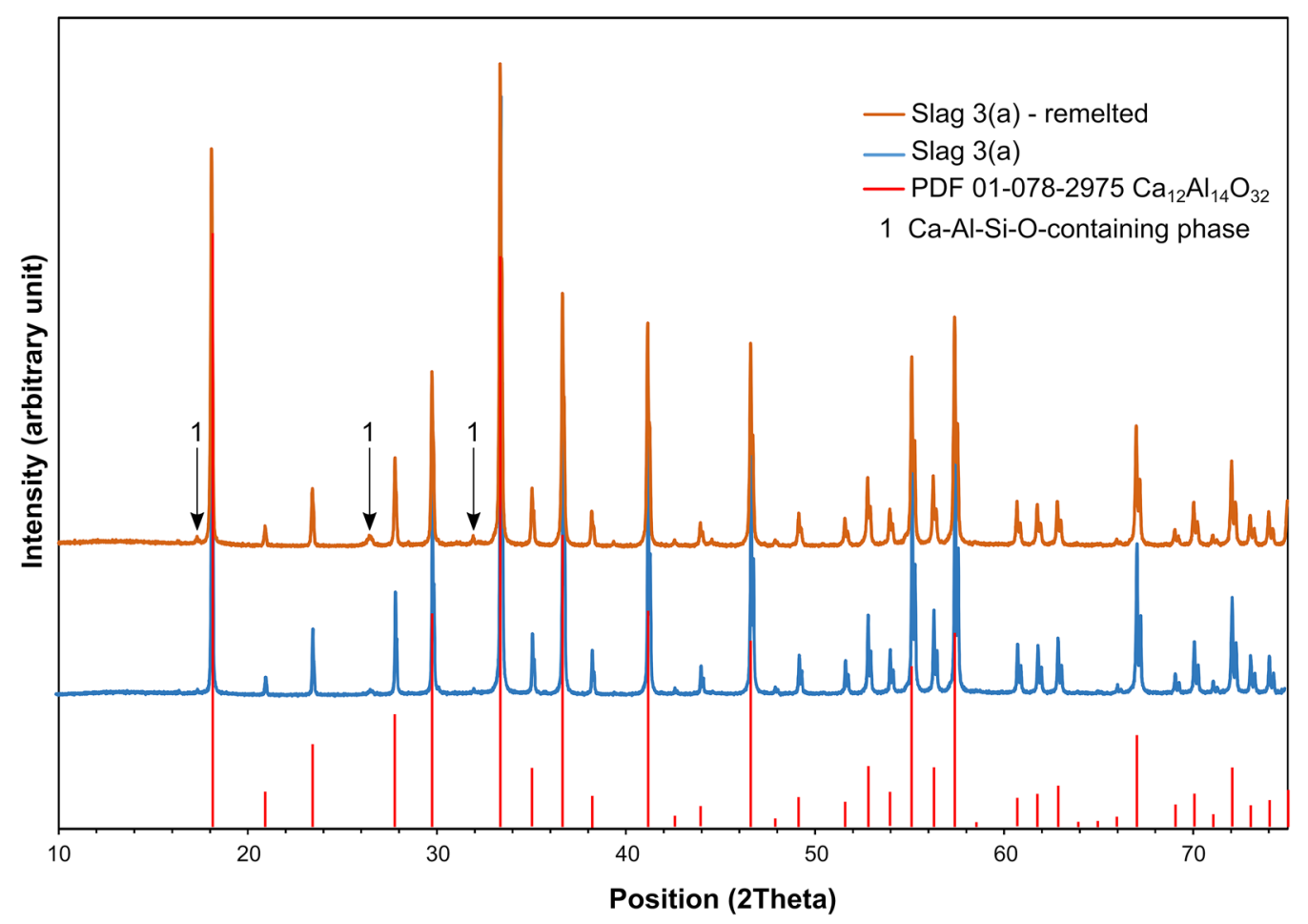

Fig. 7-XRD patterns of slag 3(a) and slag 3(a)-remelted. 


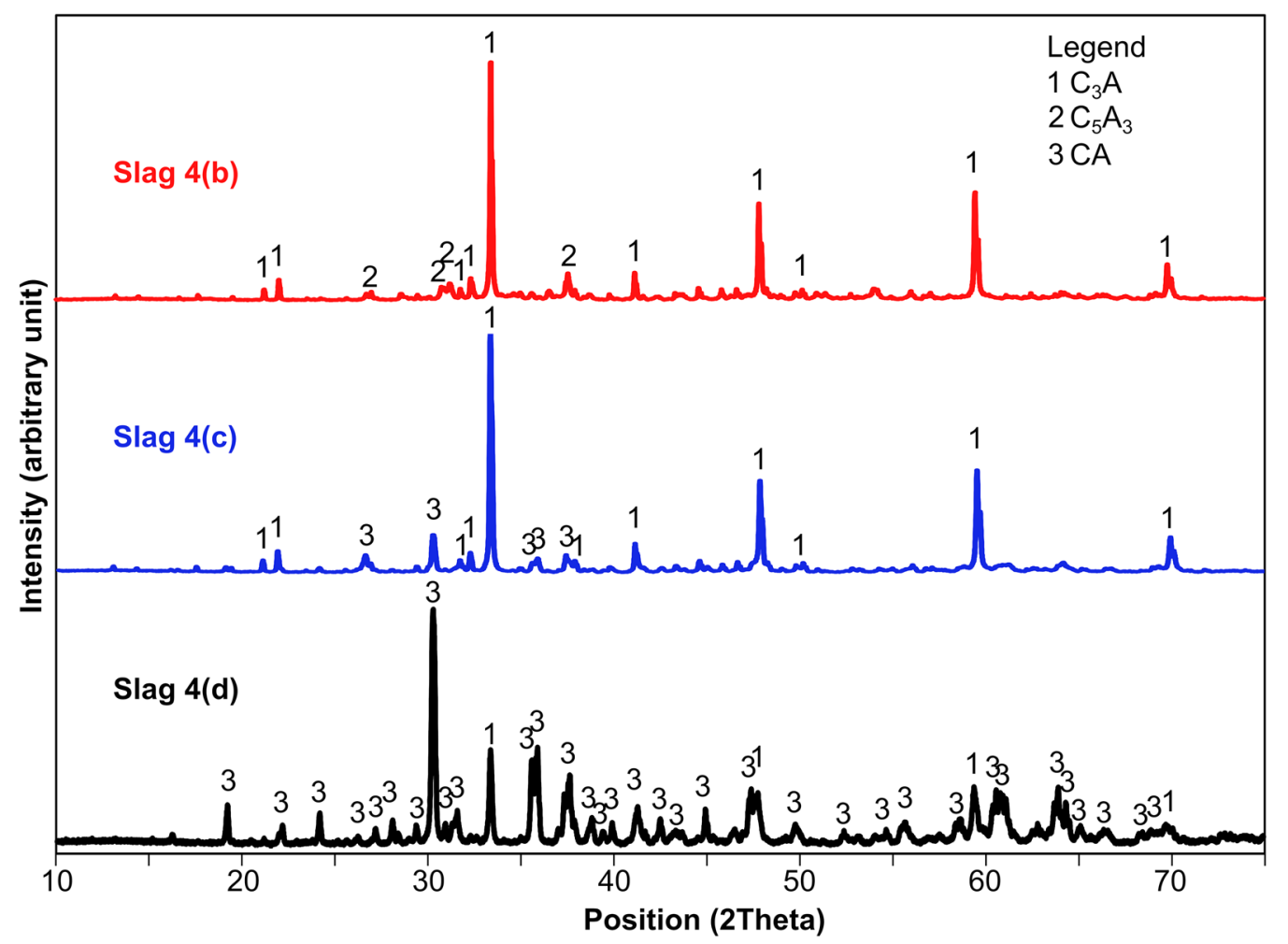

Fig. 8-XRD patterns of slags 4(b), (c), and (d), produced from pure mixtures in reducing with $\mathrm{O}_{2}$ presence, reducing, and oxidizing conditions, respectively.

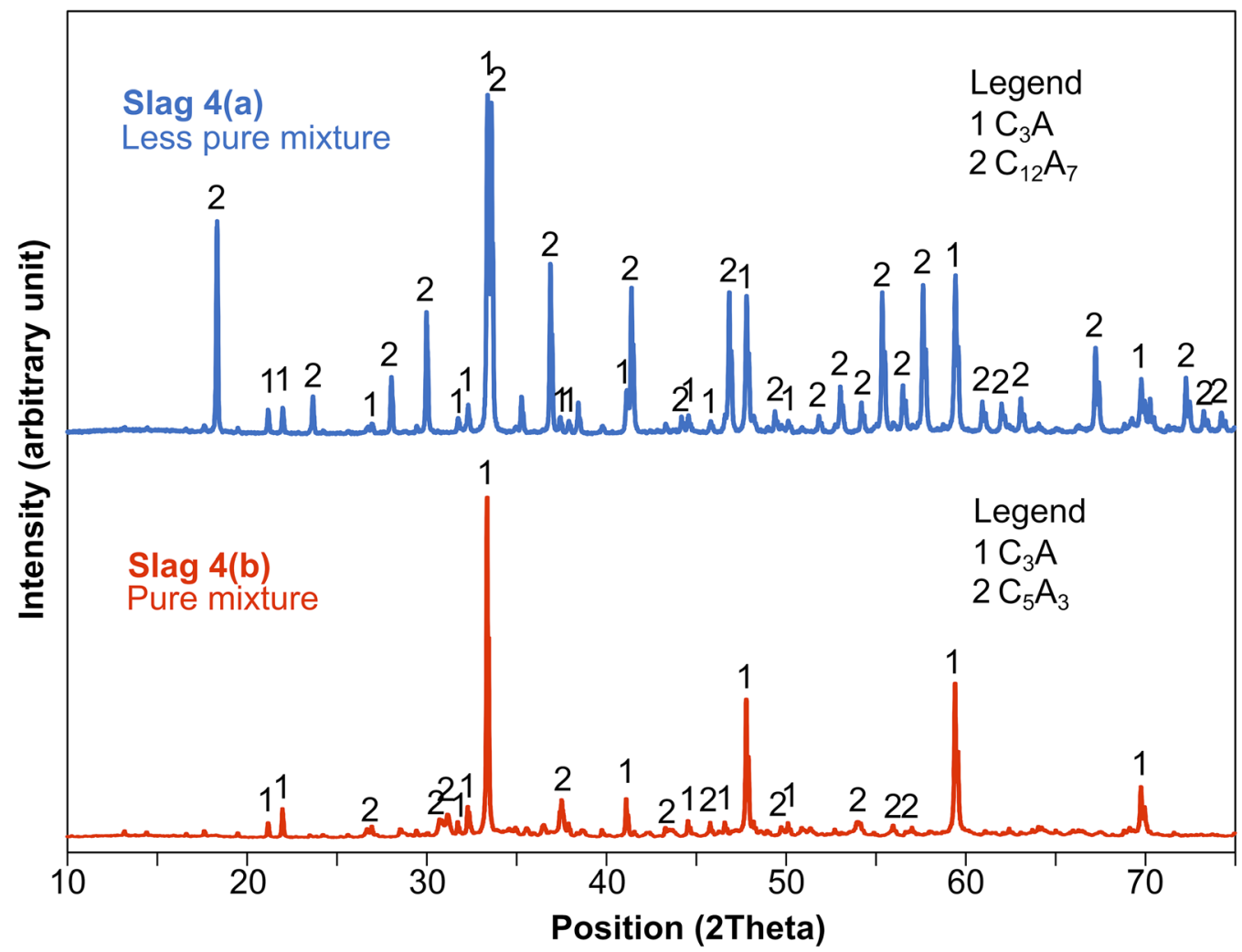

Fig. 9-XRD patterns of slags 4(a) and (b). 
Table II. Identified Phases of the Slags Which Correspond to Their Diffraction Database Number

\begin{tabular}{|c|c|c|c|}
\hline Sample Name & Identified Phases & Diffraction Database Number & References \\
\hline Slag 3(a) & $\mathrm{C}_{12} \mathrm{~A}_{7}$ & PDF 01-078-2975 & 37 \\
\hline \multirow[t]{3}{*}{ Slag 3(b) } & $\mathrm{C}_{5} \mathrm{~A}_{3}$ & COD 2106611 & 38 \\
\hline & $\mathrm{C}_{3} \mathrm{~A}$ & COD 9015966 & 39 \\
\hline & $\mathrm{CA}$ & COD 1528680 & 40 \\
\hline \multirow[t]{3}{*}{ Slag 3(c) } & $\mathrm{C}_{3} \mathrm{~A}$ & PDF 04-008-8069 & 39 \\
\hline & $\mathrm{C}_{5} \mathrm{~A}_{3}$ & PDF 04-007-2675 & 38 \\
\hline & $\mathrm{CA}$ & PDF 00-053-0191 & 41 \\
\hline \multirow[t]{2}{*}{ Slag 3(d) } & CA & PDF 00-053-0191 & 41 \\
\hline & $\mathrm{C}_{3} \mathrm{~A}$ & PDF 00-006-0495 & 42 \\
\hline Slag 3(a)-Remelted & $\mathrm{C}_{12} \mathrm{~A}_{7}$ & PDF 01-078-2975 & 37 \\
\hline \multirow[t]{2}{*}{ Slag 4(a) } & $\mathrm{C}_{3} \mathrm{~A}$ & COD 9015966 & 39 \\
\hline & $\mathrm{C}_{12} \mathrm{~A}_{7}$ & COD 8104354 & 4 \\
\hline \multirow[t]{2}{*}{ Slag 4(b) } & $\mathrm{C}_{3} \mathrm{~A}$ & PDF 00-038-1429 & 43 \\
\hline & $\mathrm{C}_{5} \mathrm{~A}_{3}$ & PDF 00-011-0357 & 44 \\
\hline \multirow[t]{2}{*}{ Slag 4(c) } & $\mathrm{C}_{3} \mathrm{~A}$ & PDF 04-008-8069 & 39 \\
\hline & $\mathrm{CA}$ & PDF 04-013-0779 & 45 \\
\hline \multirow[t]{2}{*}{ Slag 4(d) } & $\mathrm{CA}$ & PDF 00-053-0191 & 41 \\
\hline & $\mathrm{C}_{3} \mathrm{~A}$ & PDF 00-038-1429 & 43 \\
\hline
\end{tabular}
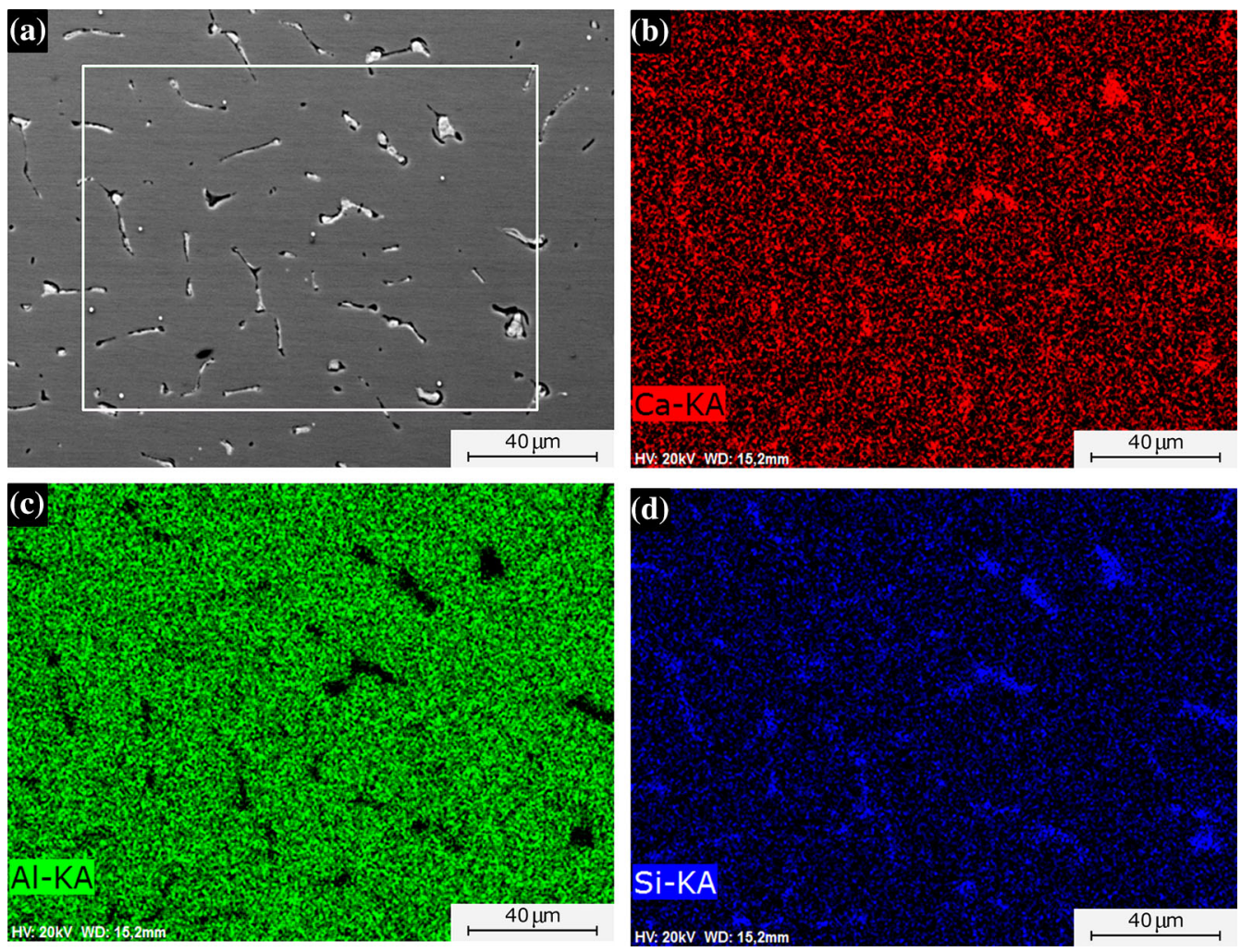

Fig. 10 - (a) BSE image of slag 3(a) where the area inside of the white rectangular line is observed by X-ray map to show different concentrations of $(b)$ calcium, $(c)$ aluminum, and $(d)$ silicon.

has a slightly higher concentration of calcium than the matrix. Also, it is shown that a relatively low silicon concentration is concentrated within the grain boundaries.

In Figure 12, a BSE image of slag 3(a) is shown. The EDS point number 825 to 831 and 832 to 839 measures the elemental composition of the Ca-Al-Si-O-containing phase and matrix, respectively. The Ca-Al-Si-O- containing phase consists of $43.27 \mathrm{wt}$ pet $\mathrm{Ca}, 27.81 \mathrm{wt}$ pct $\mathrm{Al}, 2.32$ wt pet $\mathrm{Si}, 0.82$ wt pct $\mathrm{Mg}$, and 25.78 wt pct $\mathrm{O}$, on average, as shown in Table III. However, a portion of the detected $\mathrm{Ca}, \mathrm{Al}$, and $\mathrm{O}$ may be from the matrix as this phase is small. Meanwhile, the matrix consists of $37.94 \mathrm{wt}$ pct $\mathrm{Ca}, 34.84$ wt pet, and 27.23 wt pet $\mathrm{O}$, on average (Table III). The mass ratio of $\mathrm{Ca} /(\mathrm{Al}+\mathrm{Si})$ on the 
Ca-Al-Si-O-containing phase and matrix is 1.44 and 1.09, respectively. Also, a standard deviation $(\sigma)$ is calculated and shown in the table as well.

Typical SEM-BSE images of slag 3(b) are shown in Figure 13, which includes the EDS measurement points on both the bright phase and matrix, and the EDS results are given in Table IV. On average, the bright phase consists of 45.29 wt pet $\mathrm{Ca}, 25.15$ wt pet Al, 0.09 wt pet $\mathrm{Si}$, and $29.47 \mathrm{wt}$ pet $\mathrm{O}$. Meanwhile, the matrix consists of the average composition of $42.03 \mathrm{wt}$ pct $\mathrm{Ca}$, 31.51 wt pet Al, and 26.46 wt pet $\mathrm{O}$.

BSE images of slags 3(a) and 3(b) are shown in Figures 14 and 15. The images were taken by EPMA. The BSE image of slag 3(a) confirms the equilibrium of the $\mathrm{Ca}-\mathrm{Al}$-Si-O-containing phase and $\mathrm{C}_{12} \mathrm{~A}_{7}$ on the slag. Moreover, the WDS result of randomly selected points on the phases of the slags is presented in Table V. The mass ratios of $\mathrm{CaO} /\left(\mathrm{Al}_{2} \mathrm{O}_{3}+\mathrm{SiO}_{2}\right)$ of the matrix and Ca-Al-Si-O-containing phase on slag 3(a) are 0.89 and 1.49 , respectively. Meanwhile, the mass ratio of $\mathrm{CaO} /$ $\left(\mathrm{Al}_{2} \mathrm{O}_{3}+\mathrm{SiO}_{2}\right)$ on the matrix of slag $3(\mathrm{~b})$ is 0.86 .

\section{Raman Spectroscopy}

A Raman spectrum measurement of slags 3(a) and (b) at room temperature is shown in Figure 16. The strongest band of $\mathrm{C}_{12} \mathrm{~A}_{7}$ in the present study is detected at $521 \mathrm{~cm}^{-1}$; meanwhile, other moderate intensities are seen at 312,772 , and $880 \mathrm{~cm}^{-1}$. The measured bands are in agreement with the literature. ${ }^{[46]}$ The band of bright phase on slag 3(a) that was observed in Figure 14 cannot be detected because of noises and its low quantity. On the other hand, the Raman measurement of slag $3(\mathrm{~b})$ shows that the $\mathrm{C}_{5} \mathrm{~A}_{3}$ bands at $790,601,441$, 345 , and $300 \mathrm{~cm}^{-1}$ are in relatively fair agreement with the $\mathrm{C}_{5} \mathrm{~A}_{3}$ bands in the literature. ${ }^{[47]}$ The $\mathrm{C}_{3} \mathrm{~A}$ and $\mathrm{CA}$ bands are seen at 758 and $519 \mathrm{~cm}^{-1}$, also in good agreement with the literature. ${ }^{[46]}$

In addition to room temperature, the in-situ Raman measurements of slags $3(\mathrm{a})$ and $3(\mathrm{~b})$ at $500{ }^{\circ} \mathrm{C}, 800{ }^{\circ} \mathrm{C}$, $1000{ }^{\circ} \mathrm{C}, 1200{ }^{\circ} \mathrm{C}, 1400{ }^{\circ} \mathrm{C}, 1450{ }^{\circ} \mathrm{C}$, and $1485^{\circ} \mathrm{C}$ are shown in Figures 17 and 18, respectively. In Figure 17, the $\mathrm{C}_{12} \mathrm{~A}_{7}$ band intensity at $490 \pm 10 \mathrm{~cm}^{-1}$ decreases as the temperature increases. It is worth noting that the Raman band can be shifted from room to elevated temperatures because of the structural changes of the material from the crystal to amorphous phase, as reported in the literature. ${ }^{[48]}$ Therefore, as shown in Figures 16 and 17, the $\mathrm{C}_{12} \mathrm{~A}_{7}$ band shifts as the temperature increases. Furthermore, the band is undetected at temperatures $\geq 1450{ }^{\circ} \mathrm{C}$, which indicates that the $\mathrm{C}_{12} \mathrm{~A}_{7}$ phase does not exist at these temperatures.

Moreover, the Raman measurement of slag 3(b) at elevated temperatures shows that up to $1000{ }^{\circ} \mathrm{C}$, the $\mathrm{C}_{5} \mathrm{~A}_{3}, \mathrm{C}_{3} \mathrm{~A}$, and $\mathrm{CA}$ phases are stable. At $1200{ }^{\circ} \mathrm{C}$, however, the $\mathrm{C}_{5} \mathrm{~A}_{3}$ bands are not detected, while a strong band that is located at the same location as the $\mathrm{C}_{12} \mathrm{~A}_{7}$ band is observed. This band is undetected at
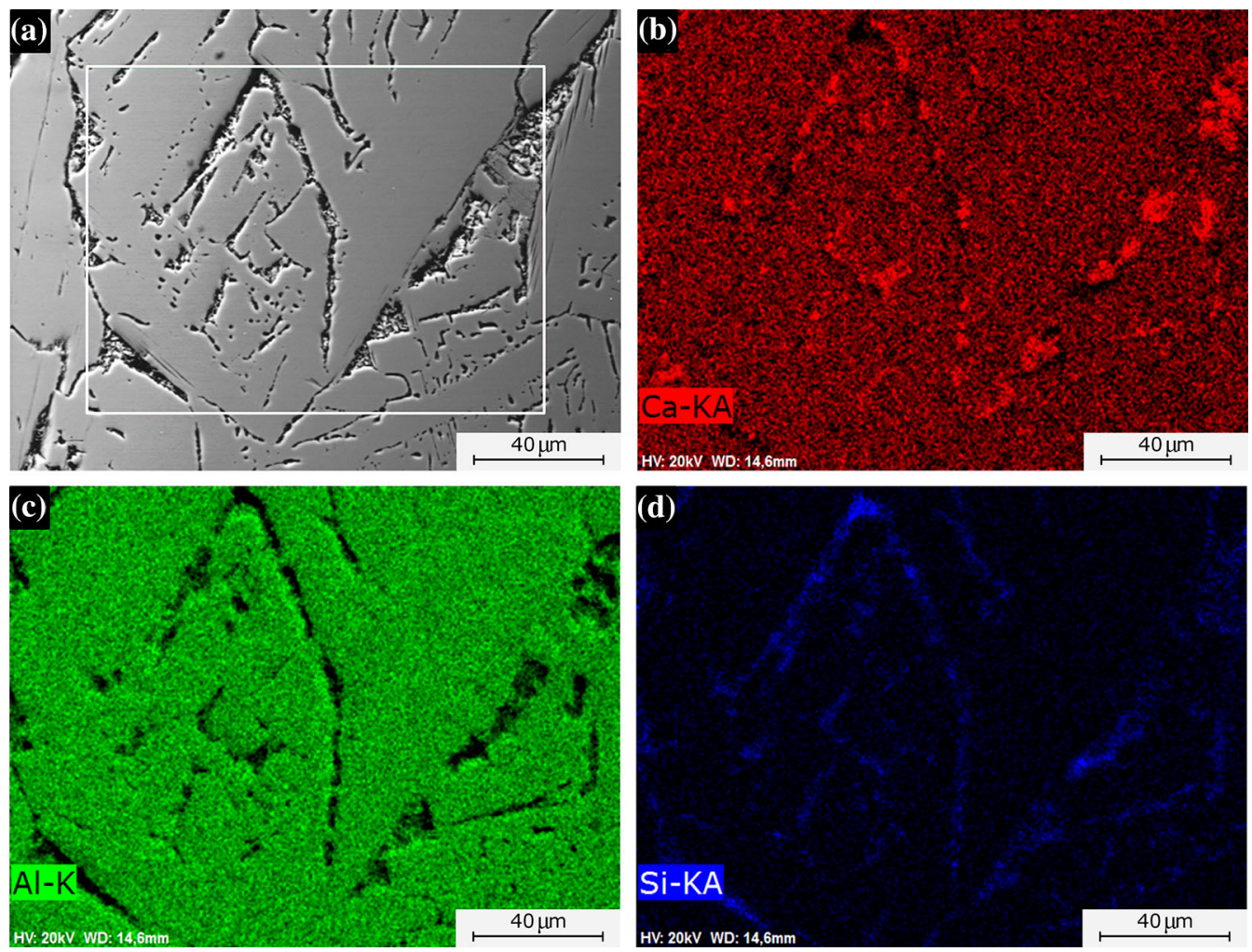

Fig. 11- (a) BSE image of slag 3(b) where the area inside of the white rectangular line is observed by X-ray map to show different concentrations of $(b)$ calcium, $(c)$ aluminum, and $(d)$ silicon. 


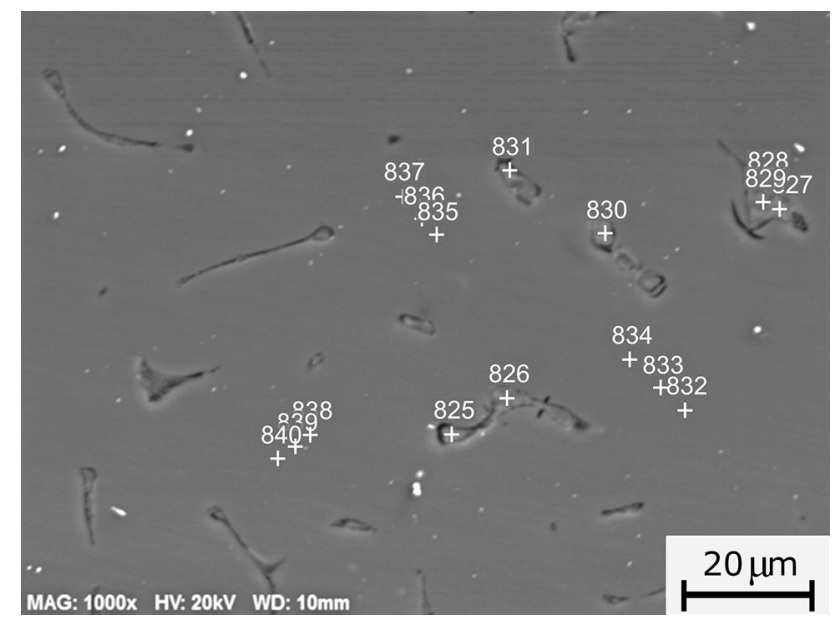

Fig. 12-SEM-BSE image of slag 3(a) with EDS point on the $\mathrm{Ca}-\mathrm{Al}$-Si-O-containing phase, which is number 825 to 831 , and the matrix, which is number 832 to 839 . temperatures $\geq 1450{ }^{\circ} \mathrm{C}$, as observed for slag 3(a). The Raman measurements at $1450{ }^{\circ} \mathrm{C}$ and $1485{ }^{\circ} \mathrm{C}$ show that one or several phases co-exist in the heated slag as some weak bands are observed at these temperatures. However, it is very difficult to identify them because of the noises and their low intensity. The noise is probably the result of the unmelted slag at these particular temperatures.

\section{E. TG-DTA Analysis}

Figure 19 shows the TG-DTA graphs of slag 3(a) from room temperature to $1500{ }^{\circ} \mathrm{C}$, which was performed in a furnace that was exposed to synthetic air, using an alumina crucible. In Figure 19(a), the significant mass loss at the beginning of the measurement should not be taken into consideration as it may have resulted from an error of weight calibration or buoyancy effect at low temperatures. It is reported that the

Table III. EDS Results of Different Phases on the Slag 3(a) in the Point Illustrated in Fig. 12

\begin{tabular}{|c|c|c|c|c|c|c|c|}
\hline \multirow[b]{2}{*}{ BSE } & \multirow[b]{2}{*}{ EDS Point } & \multicolumn{5}{|c|}{ Element (Wt Pct) } & \multirow{2}{*}{$\begin{array}{c}\text { Mass } \\
\mathrm{Ca} /(\mathrm{Al}+\mathrm{Si})\end{array}$} \\
\hline & & $\mathrm{Ca}$ & $\mathrm{Al}$ & $\mathrm{Si}$ & $\mathrm{Mg}$ & $\mathrm{O}$ & \\
\hline \multirow[t]{8}{*}{ Ca-Al-Si-O-Containing Phase } & 825 & 41.90 & 30.22 & 2.24 & 0.80 & 24.83 & 1.29 \\
\hline & 826 & 45.00 & 27.49 & 2.09 & 0.75 & 24.68 & 1.52 \\
\hline & 827 & 43.32 & 26.47 & 2.49 & 0.83 & 26.88 & 1.50 \\
\hline & 828 & 44.28 & 26.95 & 2.41 & 0.86 & 25.50 & 1.51 \\
\hline & 829 & 44.93 & 26.78 & 2.58 & 0.85 & 24.86 & 1.53 \\
\hline & 830 & 41.81 & 27.53 & 2.59 & 0.85 & 27.22 & 1.39 \\
\hline & 831 & 41.64 & 29.25 & 1.82 & 0.80 & 26.49 & 1.34 \\
\hline & average $(\sigma)$ & $43.27(1.50)$ & $27.81(1.39)$ & $2.32(0.28)$ & $0.82(0.04)$ & $25.78(1.07)$ & $1.44(0.10)$ \\
\hline \multirow[t]{9}{*}{ Matrix } & 832 & 37.92 & 34.75 & 0.00 & 0.00 & 27.33 & 1.09 \\
\hline & 833 & 37.97 & 34.73 & 0.00 & 0.00 & 27.30 & 1.09 \\
\hline & 834 & 37.94 & 34.80 & 0.00 & 0.00 & 27.26 & 1.09 \\
\hline & 835 & 38.83 & 34.10 & 0.00 & 0.00 & 27.07 & 1.14 \\
\hline & 836 & 37.50 & 35.21 & 0.00 & 0.00 & 27.29 & 1.07 \\
\hline & 837 & 37.91 & 34.91 & 0.00 & 0.00 & 27.18 & 1.09 \\
\hline & 838 & 37.35 & 35.42 & 0.00 & 0.00 & 27.23 & 1.05 \\
\hline & 839 & 38.10 & 34.76 & 0.00 & 0.00 & 27.14 & 1.10 \\
\hline & average $(\sigma)$ & $37.94(0.44)$ & $34.84(0.39)$ & $0.00(0.00)$ & $0.00(0.00)$ & $27.23(0.09)$ & $1.09(0.03)$ \\
\hline
\end{tabular}
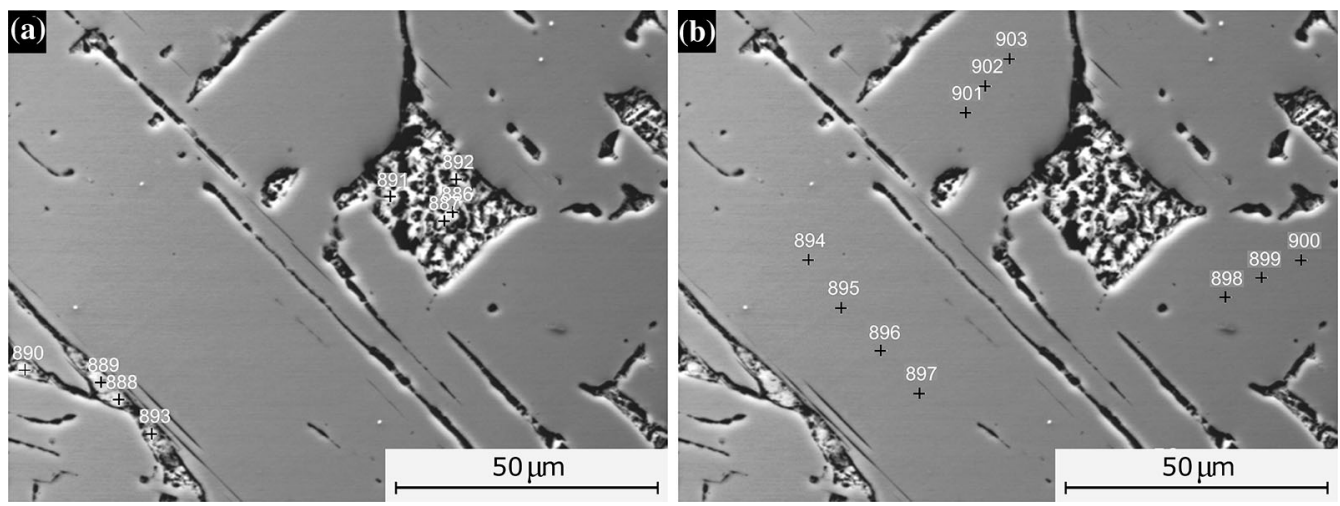

Fig. 13 - SEM-BSE images of slag 3 (b) with the EDS point on both (a) the bright phase, which is number 886 to 893 , and $(b)$ the matrix, which is number 894 to 903 . 
Table IV. EDS Result of Different Phases on the Slag 3(b)

\begin{tabular}{|c|c|c|c|c|c|c|c|}
\hline \multirow[b]{2}{*}{ BSE } & \multirow[b]{2}{*}{ EDS Point } & \multicolumn{5}{|c|}{ Element (Wt Pct) } & \multirow{2}{*}{$\begin{array}{c}\text { Mass } \\
\mathrm{Ca} /(\mathrm{Al}+\mathrm{Si})\end{array}$} \\
\hline & & $\mathrm{Ca}$ & $\mathrm{Al}$ & $\mathrm{Si}$ & $\mathrm{Mg}$ & $\mathrm{O}$ & \\
\hline \multirow[t]{9}{*}{ Bright Phase } & 886 & 37.72 & 31.86 & 0.00 & 0.00 & 30.42 & 1.18 \\
\hline & 887 & 48.20 & 27.59 & 0.00 & 0.00 & 24.21 & 1.75 \\
\hline & 888 & 50.36 & 24.02 & 0.00 & 0.00 & 25.62 & 2.10 \\
\hline & 889 & 49.81 & 22.13 & 0.00 & 0.00 & 28.06 & 2.25 \\
\hline & 890 & 50.82 & 24.01 & 0.00 & 0.00 & 25.17 & 2.12 \\
\hline & 891 & 41.89 & 23.77 & 0.00 & 0.00 & 34.34 & 1.76 \\
\hline & 892 & 35.29 & 23.83 & 0.75 & 0.00 & 40.13 & 1.44 \\
\hline & 893 & 48.24 & 23.95 & 0.00 & 0.00 & 27.81 & 2.01 \\
\hline & average $(\sigma)$ & $45.29(6.13)$ & $25.15(3.11)$ & $0.09(0.27)$ & $0.00(0.00)$ & $29.47(5.40)$ & $1.83(0.37)$ \\
\hline \multirow[t]{11}{*}{ Matrix } & 894 & 42.38 & 31.00 & 0.00 & 0.00 & 26.61 & 1.37 \\
\hline & 895 & 41.31 & 32.49 & 0.00 & 0.00 & 26.20 & 1.27 \\
\hline & 896 & 42.22 & 31.29 & 0.00 & 0.00 & 26.48 & 1.35 \\
\hline & 897 & 41.42 & 32.13 & 0.00 & 0.00 & 26.45 & 1.29 \\
\hline & 898 & 41.78 & 31.68 & 0.00 & 0.00 & 26.54 & 1.32 \\
\hline & 899 & 41.20 & 32.15 & 0.00 & 0.00 & 26.64 & 1.28 \\
\hline & 900 & 42.52 & 31.15 & 0.00 & 0.00 & 26.33 & 1.37 \\
\hline & 901 & 42.94 & 30.63 & 0.00 & 0.00 & 26.43 & 1.40 \\
\hline & 902 & 42.00 & 31.56 & 0.00 & 0.00 & 26.44 & 1.33 \\
\hline & 903 & 42.50 & 31.05 & 0.00 & 0.00 & 26.45 & 1.37 \\
\hline & average $(\sigma)$ & $42.03(0.59)$ & $31.51(0.60)$ & $0.00(0.00)$ & $0.00(0.00)$ & $26.46(0.13)$ & $1.33(0.04)$ \\
\hline
\end{tabular}
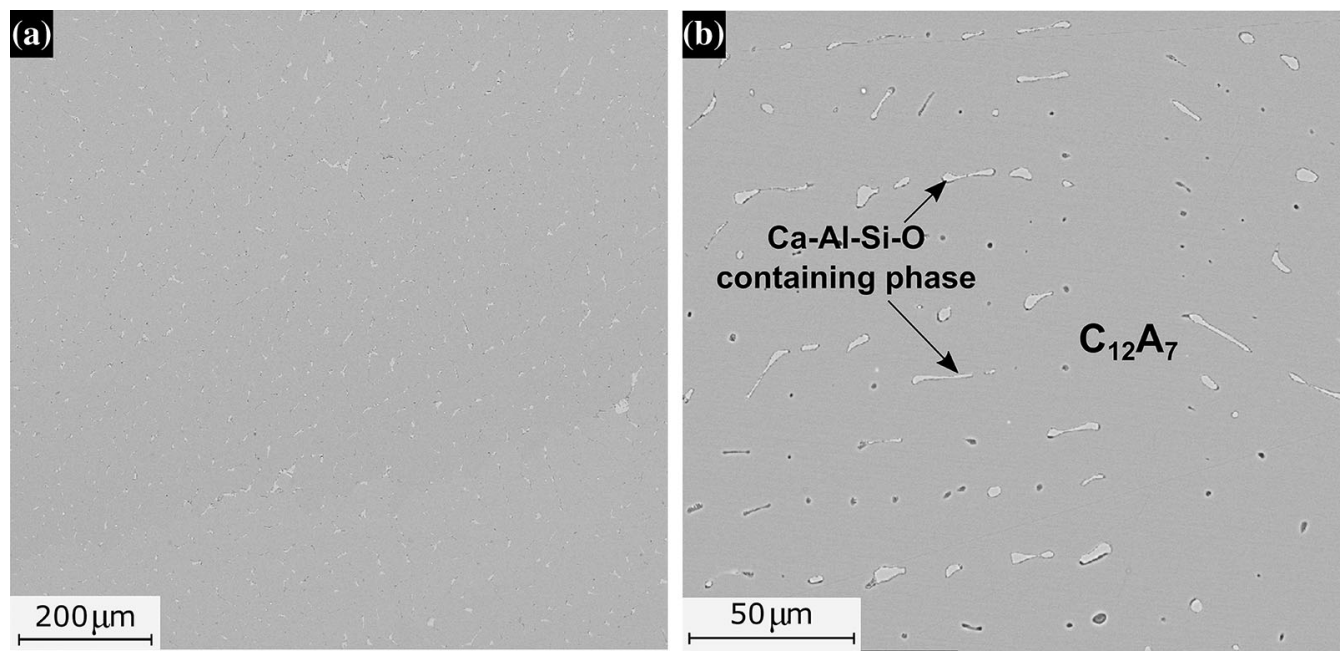

Fig. 14-BSE images of slag 3(a) taken by the EPMA instrument, which shows the matrix $\left(\mathrm{C}_{12} \mathrm{~A}_{7}\right)$ and the Ca-Al-Si-O-containing phase in $(a)$ $\times 100$ and $(b) \times 500$ magnifications.

buoyancy effect at high temperatures becomes negligible. ${ }^{[49,50]}$ It is also noted here that the TG-DTA results in the current study have been subtracted by each of the same experimental conditions without the sample. The correction runs were performed before each sample analysis.

Moreover, as seen, the sample gained mass up to 0.8 wt pct starting from $250{ }^{\circ} \mathrm{C}$ to $770{ }^{\circ} \mathrm{C}$. Then it started to lose mass of about $2 \mathrm{wt}$ pet from $770{ }^{\circ} \mathrm{C}$ to $1390{ }^{\circ} \mathrm{C}$. Therefore, in total, up to $1.2 \mathrm{wt}$ pct of the sample mass was lost compared to the original weight during the heat treatment. In Figure 19(b), several peaks of endothermic reactions during the heating step can be seen at $1270{ }^{\circ} \mathrm{C}$,
$1340{ }^{\circ} \mathrm{C}$, and $1450{ }^{\circ} \mathrm{C}$. Meanwhile, the peaks of exothermic reactions during the cooling step can be seen at $671{ }^{\circ} \mathrm{C}$ and $1180{ }^{\circ} \mathrm{C}$. Figure 19 (c) shows the overall TG-DTA result as a function of time.

Furthermore, Figure 20 shows the TG-DTA graph of slag 3(b) from room temperature to $1500{ }^{\circ} \mathrm{C}$, which was performed in the same atmospheric condition and crucible as for slag 3(a). Similar to the previous result from slag 3(a), the immediate mass loss at the beginning of the measurement should not be taken into consideration because of the weight calibration. The sample lost 0.01 wt pet mass from $76{ }^{\circ} \mathrm{C}{ }^{\circ} \mathrm{C}$ to $380{ }^{\circ} \mathrm{C}$. Then, it gained a mass of $0.05 \mathrm{wt}$ pct when the heating continued 

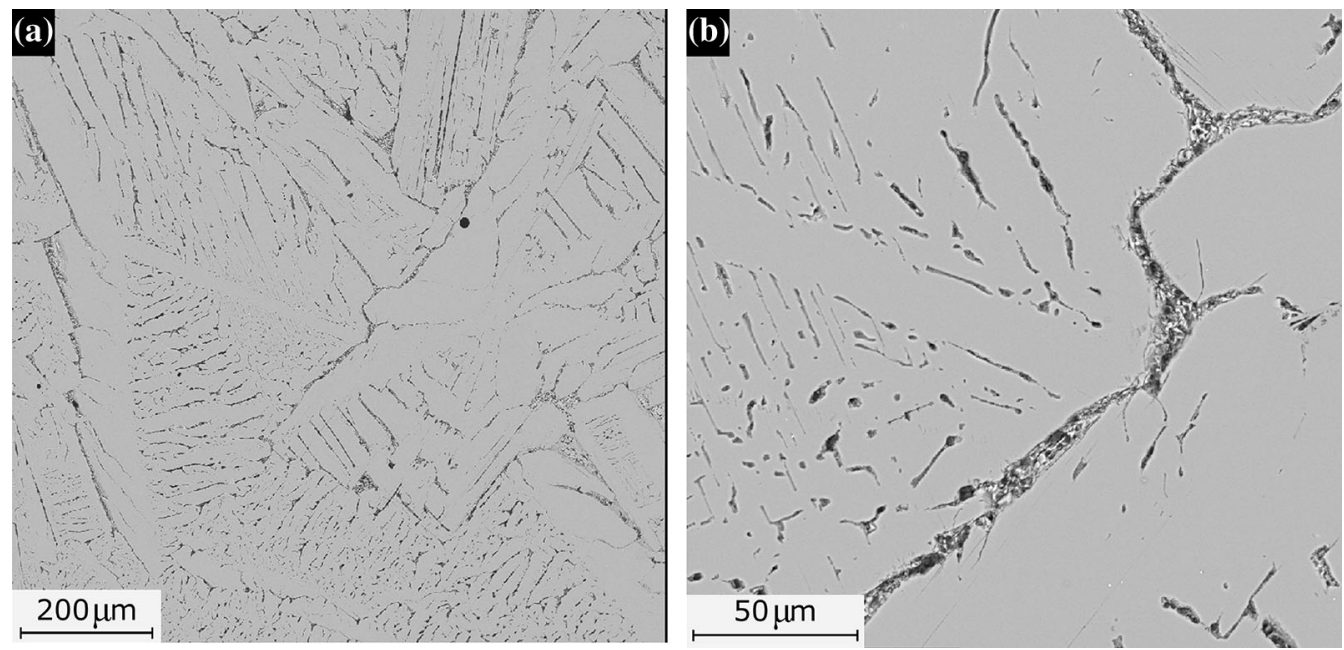

Fig. 15-BSE images of slag 3(b) taken by the EPMA instrument that shows the matrix $\left(\mathrm{C}_{5} \mathrm{~A}_{3}\right)$ and bright phase $\left(\mathrm{C}_{3} \mathrm{~A}\right)$ in $(a) \times 100$ and $(b)$ $\times 500$ magnifications.

up to $470{ }^{\circ} \mathrm{C}$. It gradually lost about 0.5 wt pet mass from $470{ }^{\circ} \mathrm{C}$ to $1310{ }^{\circ} \mathrm{C}$. Thus, from $1310{ }^{\circ} \mathrm{C}$ to $1500{ }^{\circ} \mathrm{C}$ the sample lost mass significantly up to $1.7 \mathrm{wt}$ pet. Therefore, the total mass loss is $2.1 \mathrm{wt}$ pct during heat treatment. Moreover, the several peaks of endothermic reactions during the heating step are seen at $1310{ }^{\circ} \mathrm{C}$, $1350{ }^{\circ} \mathrm{C}$, and later at $1500{ }^{\circ} \mathrm{C}$ after holding for ca. 3 minutes. On the other hand, the peaks of exothermic reactions during the cooling step are seen at $750{ }^{\circ} \mathrm{C}$ and $1220{ }^{\circ} \mathrm{C}$.

\section{DISCUSSION}

Based on the XRD, EDS, WDS, and metallography observations, the effect of both atmospheric conditions and material purity on the stability of $\mathrm{C}_{12} \mathrm{~A}_{7}$ and $\mathrm{C}_{5} \mathrm{~A}_{3}$ are discussed. Also, the evolution of phases of slags 3(a) and 3(b) from the Raman spectra and TG-DTA measurements are discussed.

\section{A. The Effect of Atmospheric Conditions and Materials Purity on $\mathrm{C}_{12} \mathrm{~A}_{7}$ Stability}

As shown in the schematic of the melting setup in Figure 2, the partial pressure of $\mathrm{O}_{2}$ or $\mathrm{CO}_{2(\mathrm{~g})}$ was conditioned by the use of different crucibles and the use of a lid to limit the contact of the melts with the surrounding air. The typical setup has been reported in the literature ${ }^{[15,19]}$ which used a graphite crucible to synthesize the $\mathrm{C}_{12} \mathrm{~A}_{7}$ phase at elevated temperatures. The $\mathrm{O}_{2(\mathrm{~g})}$ partial pressure at $1600{ }^{\circ} \mathrm{C}$ is $4.4 \times 10^{-16}$ atm as calculated using FactSage ${ }^{\mathrm{TM}}$. The calculation is in agreement with the research, ${ }^{[15]}$ which stated that heating a closed-lid graphite crucible at $1600{ }^{\circ} \mathrm{C}$ created a strongly reducing atmosphere as low as $p \mathrm{O}_{2}=10^{-16}$ atm inside of the crucible. The pressure is substantially lower than the pressure used by
Imlach, ${ }^{[8]}$ which was managed to synthesize a stable $\mathrm{C}_{12} \mathrm{~A}_{7}$ at elevated temperatures with $p \mathrm{O}_{2}=$ $10^{-8} \mathrm{~atm}$.

Based on the XRD results of slags 3(a) and 3(a)-remelted, the congruent $\mathrm{C}_{12} \mathrm{~A}_{7}$ phase is stable at either reducing atmosphere or a low partial pressure of $\mathrm{O}_{2(\mathrm{~g})}$. According to the XRD results of slags 3(b) and 3(c), the $\mathrm{C}_{5} \mathrm{~A}_{3}$ phase exists with $\mathrm{C}_{3} \mathrm{~A}$ and $\mathrm{CA}$ phases at similar atmospheric conditions. It is important to note here that $\mathrm{C}_{12} \mathrm{~A}_{7}$ does not co-exist with the $\mathrm{C}_{5} \mathrm{~A}_{3}$ phase in any given atmospheric conditions. We did not observe both $C_{12} A_{7}$ and $C_{5} A_{3}$ phases from slags $3(d)$ and $4(d)$, which were produced from the oxidizing atmosphere. We can confirm that the intensity of $\mathrm{C}_{5} \mathrm{~A}_{3}$ peaks is decreased as the partial pressure of $\mathrm{O}_{2}$ is decreased, which is shown by comparing the XRD results between slags 3(b) and (c), and between slags 4(b) and (c), where the graphite crucibles were exposed to air or closed using the lid, respectively. On the other hand, the lower intensity of the peaks due to the change of $\mathrm{O}_{2}$ (g) partial pressure is not seen in the $\mathrm{C}_{12} \mathrm{~A}_{7}$ phase. We did not proceed to smelt a series of Slag 4 (a) that contains $\mathrm{C}_{12} \mathrm{~A}_{7}$ in equilibrium with the $\mathrm{C}_{3} \mathrm{~A}$ phase at different atmospheric conditions. However, the re-melting of slag 3(a) at reducing condition only produces a congruent $\mathrm{C}_{12} \mathrm{~A}_{7}$ phase. Therefore, the intensity of $\mathrm{C}_{12} \mathrm{~A}_{7}$ peaks on the slag 3(a)-remelted sample cannot be compared with the original slag 3(a).

In an equilibrium condition, only two-phase regions can exist except the invariant points. However, as shown in the XRD results in Figures 5 and 8, there are three co-existing phases in slag (b) and (c), in which only pure samples were mixed. It is suggested that the metastable $\mathrm{C}_{5} \mathrm{~A}_{3}$ phase likely resulted from a continuous cooling. If the experiment was held at elevated temperatures below the solidus or was cooled down much more slowly than the current experiment, then we could see only two phases exist. 
According to the EDS and WDS results on the matrix and Ca-Al-Si-O-containing phase of slag 3(a), the major impurity in the $\mathrm{CaO}-\mathrm{Al}_{2} \mathrm{O}_{3}$ slag impurities is $\mathrm{SiO}_{2}$, which is $2.75 \mathrm{wt}$ pct, on average. The other contaminants, i.e., $\mathrm{TiO}_{2}, \mathrm{MgO}, \mathrm{MnO}, \mathrm{FeO}$, and $\mathrm{P}_{2} \mathrm{O}_{5}$, accumulatively constitute $<1 \mathrm{wt}$ pct of the slag. Therefore, it is more interesting to investigate the effect of the silicon element (or $\mathrm{SiO}_{2}$ ) on the stability of the $\mathrm{C}_{12} \mathrm{~A}_{7}$ phase than that of the other impurities.

Based on the phase and microstructure observations, it is evident that $\mathrm{SiO}_{2}$ acts as one of the essential factors in the stabilization of $\mathrm{C}_{12} \mathrm{~A}_{7}$ at room temperature, as the phase occurs only at slags produced from less pure mixtures. On slag 3(a), $\mathrm{SiO}_{2}$ exists either in the matrix $\left(\mathrm{C}_{12} \mathrm{~A}_{7}\right)$ in a solute component in the $\mathrm{C}_{12} \mathrm{~A}_{7}$ lattice or in the $\mathrm{Ca}-\mathrm{Al}$-Si-O-containing phase. We propose two of the most likely explanations for how silicon or $\mathrm{SiO}_{2}$ in both the matrix and solid solution phase can stabilize $\mathrm{C}_{12} \mathrm{~A}_{7}$ :

(1) In the $\mathrm{C}_{12} \mathrm{~A}_{7}$ matrix, the silicon cations may stabilize the extra framework $\mathrm{O}^{2-}$ anions in $\mathrm{C}_{12} \mathrm{~A}_{7}$ unit cells, which prevent the anions from leaving the cages in reducing conditions. Hence, this prevents the $\mathrm{C}_{12} \mathrm{~A}_{7}$ from decomposing to either $\mathrm{C}_{5} \mathrm{~A}_{3}$ and $\mathrm{C}_{3} \mathrm{~A}^{[51]}$ or $\mathrm{C}_{3} \mathrm{~A}$ and $\mathrm{CA}$ phases. ${ }^{[5,8,15]}$ The $\mathrm{C}_{12} \mathrm{~A}_{7}$ lattice might be slightly changed because of the $\mathrm{Si}-\mathrm{O}$ bond in the matrix.

(2) In the $\mathrm{Ca}-\mathrm{Al}-\mathrm{Si}-\mathrm{O}$ secondary phase, $\mathrm{SiO}_{2}$ may act as a "supporting phase" that helps $\mathrm{C}_{12} \mathrm{~A}_{7}$ retain its structure at elevated temperatures and a very low $\mathrm{O}_{2}$ (g) partial pressure. The $\mathrm{Ca}-\mathrm{Al}-\mathrm{Si}-\mathrm{O}-$ containing phase consists of oxides that may become the primary donor of $\mathrm{O}^{2-}$ ions to the $\mathrm{C}_{12} \mathrm{~A}_{7}$ unit cell at elevated temperatures in reducing atmospheres.

\section{The carbon effects}

In addition to silicon, another impurity that contributes to the stability of $\mathrm{C}_{12} \mathrm{~A}_{7}$ is $\mathrm{C}_{2}^{2-}$ anions, which can substitute $\mathrm{O}^{2-}$ anions in reducing conditions. The $\mathrm{C}_{2}{ }^{2-}$ anions originate from the graphite crucible. Kim et al. ${ }^{[19]}$ claimed that the $\mathrm{C}_{2}{ }^{2-}$ ions dissolve into the melt from the graphite crucible to compensate for the oxygen deficiency in $\mathrm{C}_{12} \mathrm{~A}_{7}$, which makes the $\mathrm{C}_{12} \mathrm{~A}_{7}$ phase stable in reducing atmosphere. The $\mathrm{C}_{2}{ }^{2-}$ and $\mathrm{O}^{2-}$ have close anion sizes, which are 1.2 and $1.4 \AA$, respectively. Thus, the $\mathrm{C}_{2}{ }^{2-}$ ions may act as a template instead of the extra framework $\mathrm{O}^{2-}$ in the cages. In the current work, all $\mathrm{C}_{12} \mathrm{~A}_{7}$-containing slags, i.e., slags 3(a), remelted-3(a), and 4(a), were produced from reducing atmosphere by using graphite crucibles, which are in agreement with the result from Kim et al. However, as seen in the XRD patterns of slags 3(b), 3(c), 4(b), and 4(c), these slags were melted using a graphite crucible as well, yet no $\mathrm{C}_{12} \mathrm{~A}_{7}$ phase was detected on the slags. Instead of $\mathrm{C}_{12} \mathrm{~A}_{7}$, the $\mathrm{C}_{5} \mathrm{~A}_{3}, \mathrm{C}_{3} \mathrm{~A}$, and $\mathrm{CA}$ phases are in equilibrium in these slags. Therefore, we suggest that the decomposition of $\mathrm{C}_{12} \mathrm{~A}_{7}$ to $\mathrm{C}_{5} \mathrm{~A}_{3}, \mathrm{C}_{3} \mathrm{~A}$, and $\mathrm{CA}$ follows a path as shown in reaction (1): 


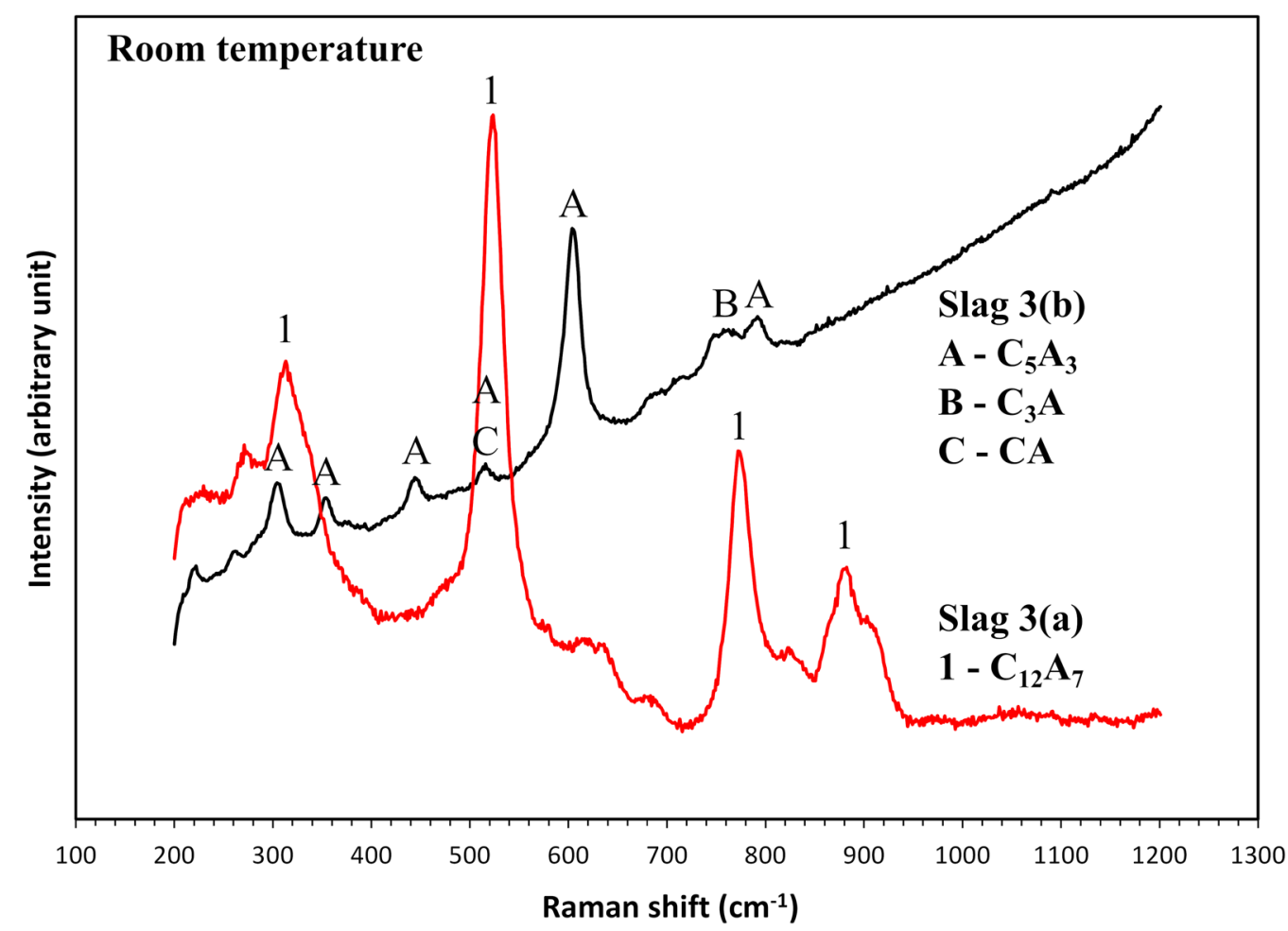

Fig. 16-Raman spectra of slags 3(a) and (b) at room temperature.

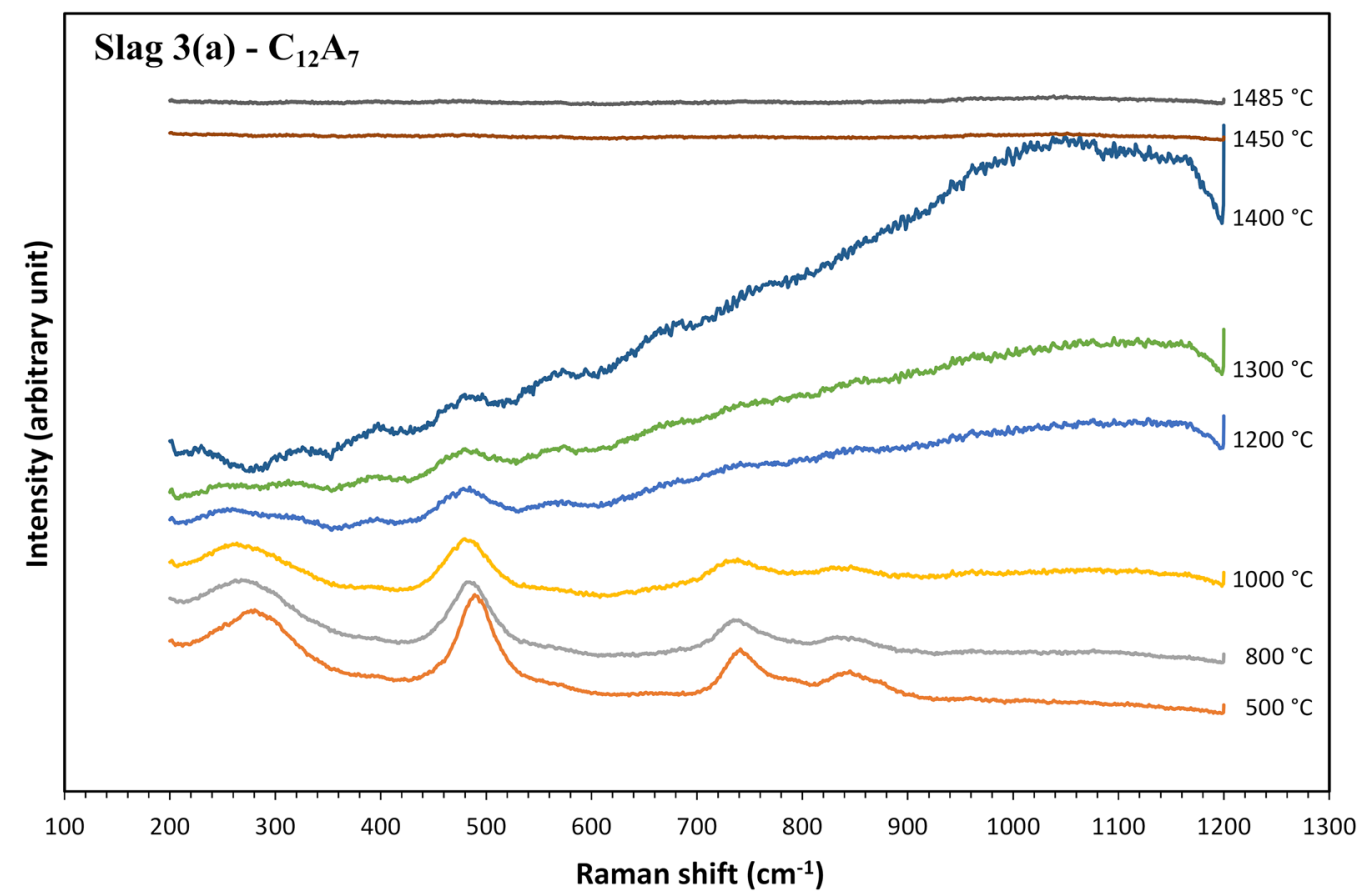

Fig. 17-In-situ Raman spectroscopy result of slag 3(a) at $500{ }^{\circ} \mathrm{C}, 800{ }^{\circ} \mathrm{C}, 1000{ }^{\circ} \mathrm{C}, 1200{ }^{\circ} \mathrm{C}, 1300{ }^{\circ} \mathrm{C}, 1400{ }^{\circ} \mathrm{C}, 1450{ }^{\circ} \mathrm{C}$, and $1485{ }^{\circ} \mathrm{C}$.

$$
\begin{aligned}
2\left(12 \mathrm{CaO} \cdot 7 \mathrm{Al}_{2} \mathrm{O}_{3}\right) \rightarrow & 4\left(5 \mathrm{CaO} \cdot 3 \mathrm{Al}_{2} \mathrm{O}_{3}\right)+3 \mathrm{CaO} \\
& \cdot \mathrm{Al}_{2} \mathrm{O}_{3}+\mathrm{CaO} \cdot \mathrm{Al}_{2} \mathrm{O}_{3}
\end{aligned}
$$

The decomposition of $\mathrm{C}_{12} \mathrm{~A}_{7}$ to three different phases may seem a complex solid-state phase transformation, which is dependent on the kinetics rate of crystallization. This is supported by a study done by Zhmoidin and 


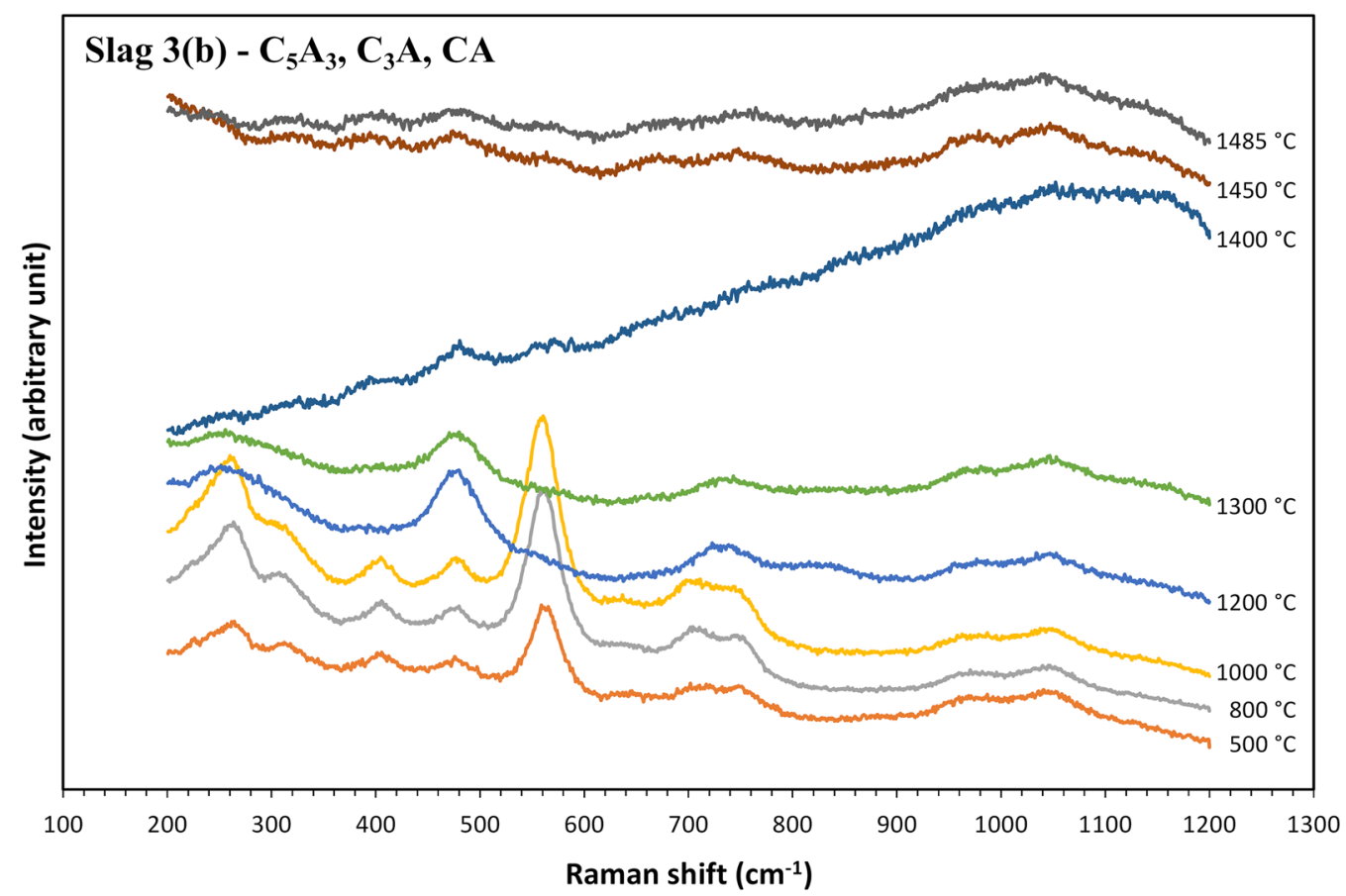

Fig. 18 - In-situ Raman spectroscopy analysis of slag $3\left(\right.$ b) at $500{ }^{\circ} \mathrm{C}, 800{ }^{\circ} \mathrm{C}, 1000{ }^{\circ} \mathrm{C}, 1200{ }^{\circ} \mathrm{C}, 1300{ }^{\circ} \mathrm{C}, 1400{ }^{\circ} \mathrm{C}, 1450{ }^{\circ} \mathrm{C}$, and $1485{ }^{\circ} \mathrm{C}$.

Chatterjee. ${ }^{[52]}$ They reported the removal of stabilizing additives (gases or anion template) from $\mathrm{C}_{12} \mathrm{~A}_{7}$ or its melt leads to the densification of the structure with the formation of $\mathrm{C}_{5} \mathrm{~A}_{3}$ or a mixture of $\mathrm{C}_{5} \mathrm{~A}_{3}, \mathrm{C}_{3} \mathrm{~A}$, and $\mathrm{CA}$.

Based on the XRD results of slags 3(b), 3(c), 4(b), and 4(c), we suggest that the role of $\mathrm{C}_{2}{ }^{2-}$ ions on the stabilization of $\mathrm{C}_{12} \mathrm{~A}_{7}$ is not significant in a one-stage melting treatment. The result is in agreement with the study from Kim et al., ${ }^{[19]}$ in which they needed a two-stage melting treatment at $1600{ }^{\circ} \mathrm{C}$ to produce a stable $\mathrm{C}_{12} \mathrm{~A}_{7}$ at room temperature using a graphite crucible. As we successfully synthesized a stable $\mathrm{C}_{12} \mathrm{~A}_{7}$ only in a one-stage melting treatment (slag 3(a)), we may conclude that the silicon or $\mathrm{SiO}_{2}$ impurity in the mixture is a more significant factor than that of $\mathrm{C}_{2}{ }^{2-}$ ions on the stabilization of the $\mathrm{C}_{12} \mathrm{~A}_{7}$ phase.

\section{B. The Evolution of $C_{12} A_{7}$ and $C_{5} A_{3}$ Phases at Elevated Temperatures}

Table VI shows the evolution of the $\mathrm{C}_{12} \mathrm{~A}_{7}$ phase in slag 3(a) at elevated temperatures based on TG-DTA measurement. It is important to consider that the TG-DTA measurement was performed under an oxidizing atmosphere. It was exposed to synthetic air with a flow rate of $30 \mathrm{~mL} / \mathrm{min}$ in an alumina crucible.

Table VII shows the evolution of the $\mathrm{C}_{5} \mathrm{~A}_{3}$ phase on slag 3(b) at elevated temperatures based on the TG-DTA measurement.

In addition to the TG-DTA result of $\mathrm{C}_{5} \mathrm{~A}_{3}$ described above, it was found that the $\mathrm{C}_{5} \mathrm{~A}_{3}$ phase is unstable in the oxidizing condition when it is heated at temperatures $>1100{ }^{\circ} \mathrm{C}$, as seen in the in-situ Raman spectra measurement in Figure 18. At these temperatures, the
$\mathrm{C}_{5} \mathrm{~A}_{3}$ bands disappear and at the same time, the $\mathrm{C}_{12} \mathrm{~A}_{7}$ phase occurs in the slag. Hence, we suggest that the slag absorbs the necessary $\mathrm{O}_{2}$ gas or $\mathrm{O}^{2-}$ anions from the atmosphere to constitute a stable $\mathrm{C}_{12} \mathrm{~A}_{7}$ at elevated temperatures.

Based on the experimental results obtained in the current study and the supportive literature data, ${ }^{[5,15,51]} \mathrm{a}$ box chart showing the stability of the $\mathrm{C}_{12} \mathrm{~A}_{7}$ phase formed from the liquid state in different atmospheric conditions and purity is presented in Figure 21. Explanations regarding the figure are as follows:

1. A slag that is made from melting a pure mixture of $\mathrm{CaO}$ and $\mathrm{Al}_{2} \mathrm{O}_{3}$ in a reducing atmosphere is unlikely to have the $\mathrm{C}_{12} \mathrm{~A}_{7}$ phase according to the authors' results in the current study and literature. ${ }^{[6,16]}$ An exception was a report after Kim et al., ${ }^{[15]}$ in which they smelted the mixture two times before they obtained the $\mathrm{C}_{12} \mathrm{~A}_{7}$ phase.

2. In an oxidizing condition using a pure mixture, Nurse et al. ${ }^{[5]}$ stated that the $\mathrm{C}_{12} \mathrm{~A}_{7}$ phase can be obtained when a certain level of moisture is accessible. This agrees with the authors' current results, where $\mathrm{C}_{3} \mathrm{~A}$ and $\mathrm{CA}$ are produced from the liquid slag instead of the $\mathrm{C}_{12} \mathrm{~A}_{7}$ phase.

3. We suggest that a stable $\mathrm{C}_{12} \mathrm{~A}_{7}$ phase can be obtained from a calcium-aluminate melt with a proper composition that contains impurities that are exposed in either a reducing or oxidizing atmosphere by using an inert crucible. A suitable crucible to contain the melt during the treatment is deemed necessary to produce a stable $\mathrm{C}_{12} \mathrm{~A}_{7}$ at room temperature. An alumina crucible is not suitable to produce $\mathrm{C}_{12} \mathrm{~A}_{7}$, as no $\mathrm{C}_{12} \mathrm{~A}_{7}$ phase was obtained at room temperature using an alumina crucible. The reason is the dissolution of the 


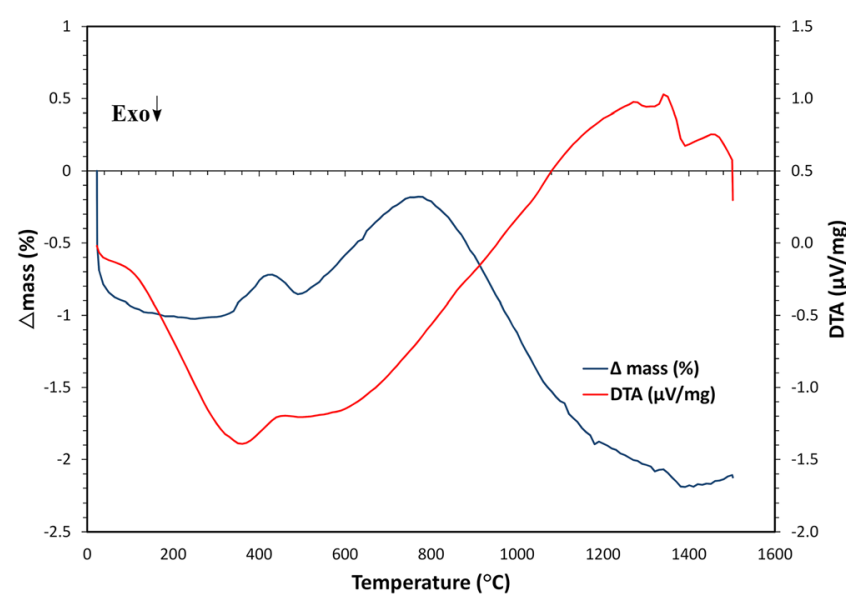

(a)

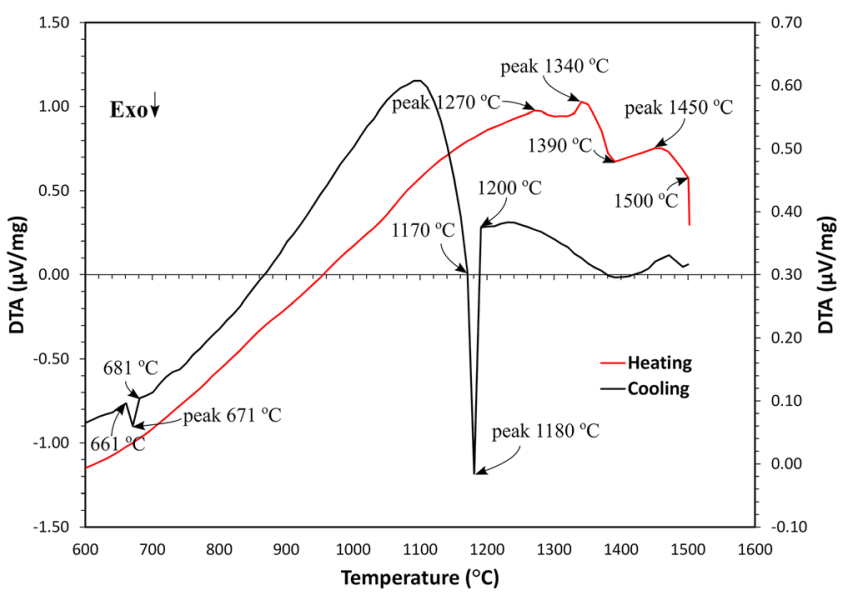

(b)

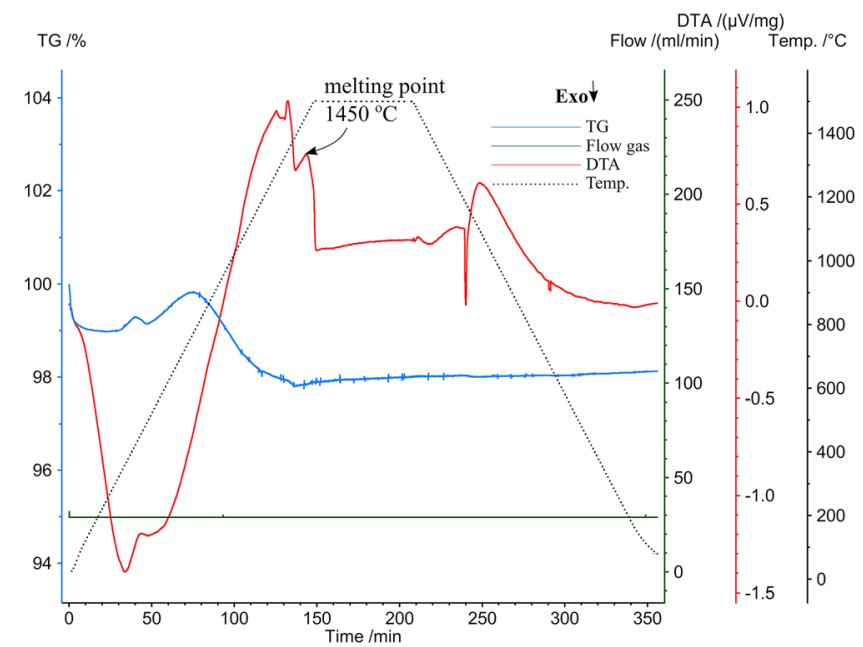

(c)

Fig. 19-TG-DTA graph of slag 3(a) that shows: (a) the change of mass percentage (pct) and DTA curve $(\mu \mathrm{V} / \mathrm{mg})$ as a function of temperature, (b) the differential of energy during heating and cooling steps at $600{ }^{\circ} \mathrm{C}$ to $1500{ }^{\circ} \mathrm{C}$, and $(c)$ TG-DTA as a function of time.

alumina crucible into the melt upon a treatment that destabilizes the $\mathrm{C}_{12} \mathrm{~A}_{7}$ phase.

4. The effect of less-pure materials and the use of an inert crucible on the stability of $\mathrm{C}_{12} \mathrm{~A}_{7}$ have never been reported before. Therefore, the current results could be useful for further research or industrial use in manufacturing $\mathrm{C}_{12} \mathrm{~A}_{7}$ in a relatively simple method.

\section{Updating the $\mathrm{CaO}-\mathrm{Al}_{2} \mathrm{O}_{3}-\mathrm{SiO}_{2}$ Phase Diagram at Low $\mathrm{SiO}_{2}$ Concentrations}

The updated $\mathrm{CaO}-\mathrm{Al}_{2} \mathrm{O}_{3}-\mathrm{SiO}_{2}$ phase diagram at low $\mathrm{SiO}_{2}$ mass fraction that includes the $\mathrm{C}_{12} \mathrm{~A}_{7}$ phase is shown in Figure 22, which is constructed using FactSage $^{\mathrm{TM}}$ by considering the obtained results of this work. The maximum solubility of $\mathrm{SiO}_{2}$ in $\mathrm{C}_{12} \mathrm{~A}_{7}$ phase is calculated as the following equation:

$$
\left.\mathrm{SiO}_{2} \max (\text { wt pct })=7.482-0.0682 \times \mathrm{Al}_{2} \mathrm{O}_{3} \text { (wt pct }\right)
$$

The maximum $\mathrm{SiO}_{2}$ solubility in the $\mathrm{C}_{12} \mathrm{~A}_{7}$ phase is a mathematical equation of curve $\mathrm{a}-\mathrm{b}$ in the diagram in Figure 22, which is valid for $\mathrm{Al}_{2} \mathrm{O}_{3}$ concentrations between 41 and $45 \mathrm{wt}$ pct. The $\mathrm{C}_{12} \mathrm{~A}_{7}$ phase is called mayenite in the literature, and as it was proved that it is stabilized by the silicon component, it is logical to call it Si-mayenite here. In other words, we suggest that both the matrix and $\mathrm{Ca}-\mathrm{Al}-\mathrm{Si}-\mathrm{O}-$-containing phases as indicated in Figures 12 and 14 are Si-mayenite. The one that contains less $\mathrm{Si}$ is a primary phase (matrix), and the other, which contains higher silica, is a eutectic phase, which is formed from a richer silica melt. This corresponds to Figure 22. The introduction of a small amount of $\mathrm{SiO}_{2}$ to the stoichiometric $\mathrm{C}_{12} \mathrm{~A}_{7}$ causes its crystal structure stability to be in a significantly wider compositional range in which the ratio of $C /(A+S)$ is almost fixed, while $C / A$ is changed to larger numbers than the stoichiometric molar ratios in $\mathrm{C}_{12} \mathrm{~A}_{7}$ in the Si-mayenite. The provided phase diagram data in Figure 22 show that the Si-mayenite can dissolve a 


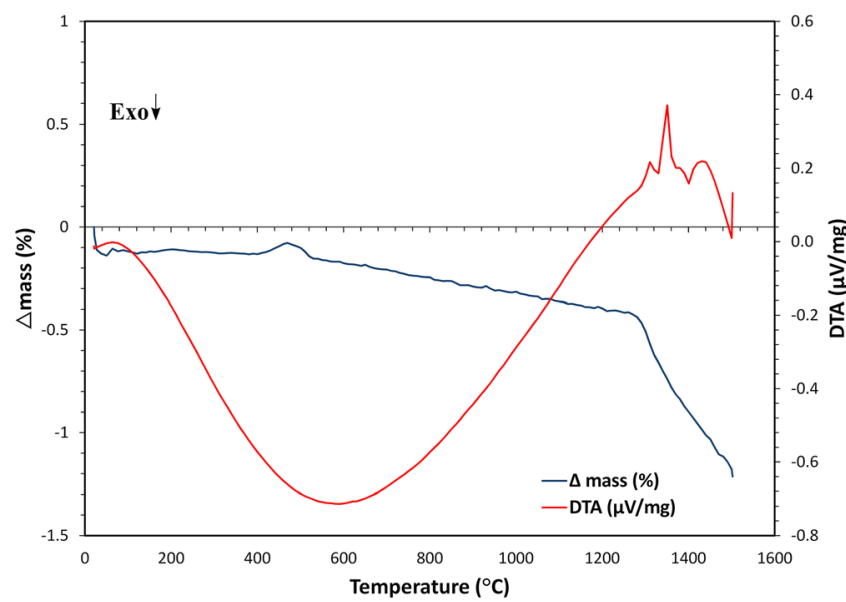

(a)

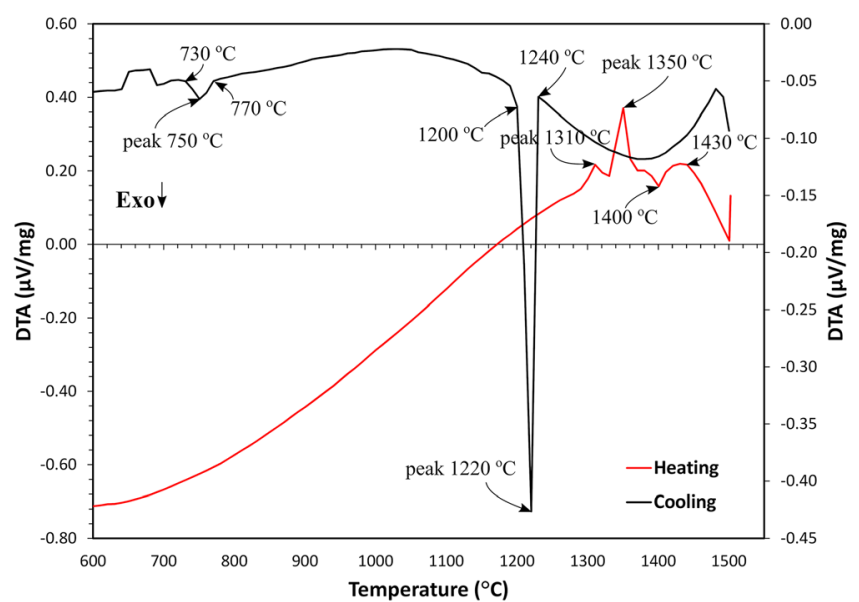

(b)

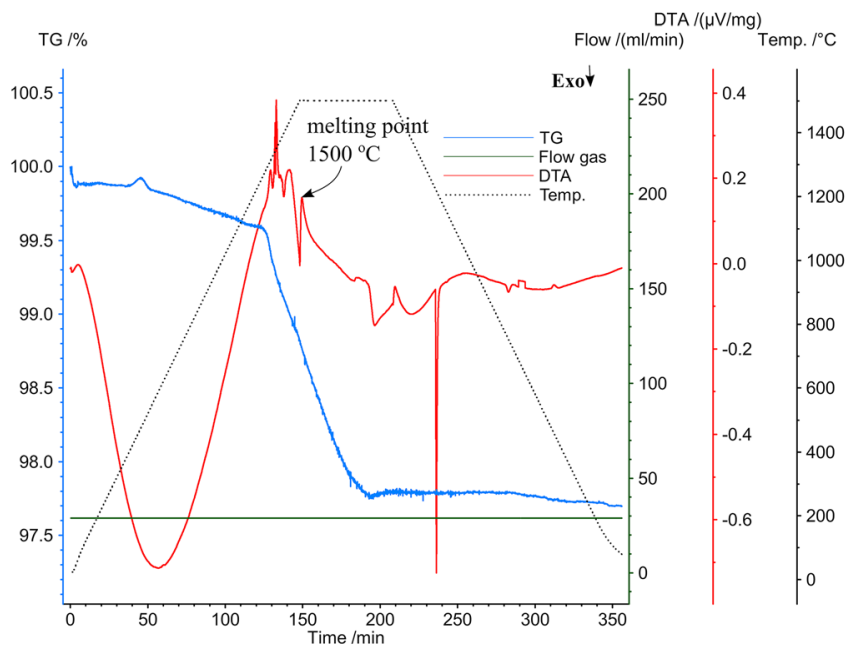

(c)

Fig. 20-TG-DTA graph of slag 3(b) that shows: $(a)$ the change of mass percentage (pet) and DTA curve $(\mu \mathrm{V} / \mathrm{mg})$ as a function of temperature, (b) the differential of energy during heating and cooling steps at $600{ }^{\circ} \mathrm{C}$ to $1500{ }^{\circ} \mathrm{C},(c)$ TG-DTA as a function of time.

maximum amount of around 4.7 wt pet $\mathrm{SiO}_{2}$. However, the amount of silica in Si-mayenite depends on the total silica in the system and also the $\mathrm{Ca} / \mathrm{Al}$ ratio.

\section{CONCLUDING REMARKS}

The stability of $12 \mathrm{CaO} \cdot 7 \mathrm{Al}_{2} \mathrm{O}_{3}$ and $5 \mathrm{CaO} \cdot 3 \mathrm{Al}_{2} \mathrm{O}_{3}$ phases at room temperature produced from melts that are exposed to different atmospheric conditions and various raw materials purity was investigated. The main conclusions of this work are summarized as:
- The dehydration of the $12 \mathrm{CaO} \cdot 7 \mathrm{Al}_{2} \mathrm{O}_{3}$ phase takes place at $770{ }^{\circ} \mathrm{C}$ to $1390{ }^{\circ} \mathrm{C}$ upon heating before it melts congruently at $14500^{\circ} \mathrm{C}$.

- Stable $12 \mathrm{CaO} \cdot 7 \mathrm{Al}_{2} \mathrm{O}_{3}$ phase at room temperature is evident, which is enforced by impurities, i.e., $\mathrm{SiO}_{2}$, which plays a significant role in maintaining the $12 \mathrm{CaO} \cdot 7 \mathrm{Al}_{2} \mathrm{O}_{3}$ structure with good reproducibility.

- As the silicon stabilizes the $12 \mathrm{CaO} \cdot 7 \mathrm{Al}_{2} \mathrm{O}_{3}$ phase (Si-mayenite), it is possible to produce a stable phase in either reducing or oxidizing atmosphere by using a single melting process. 


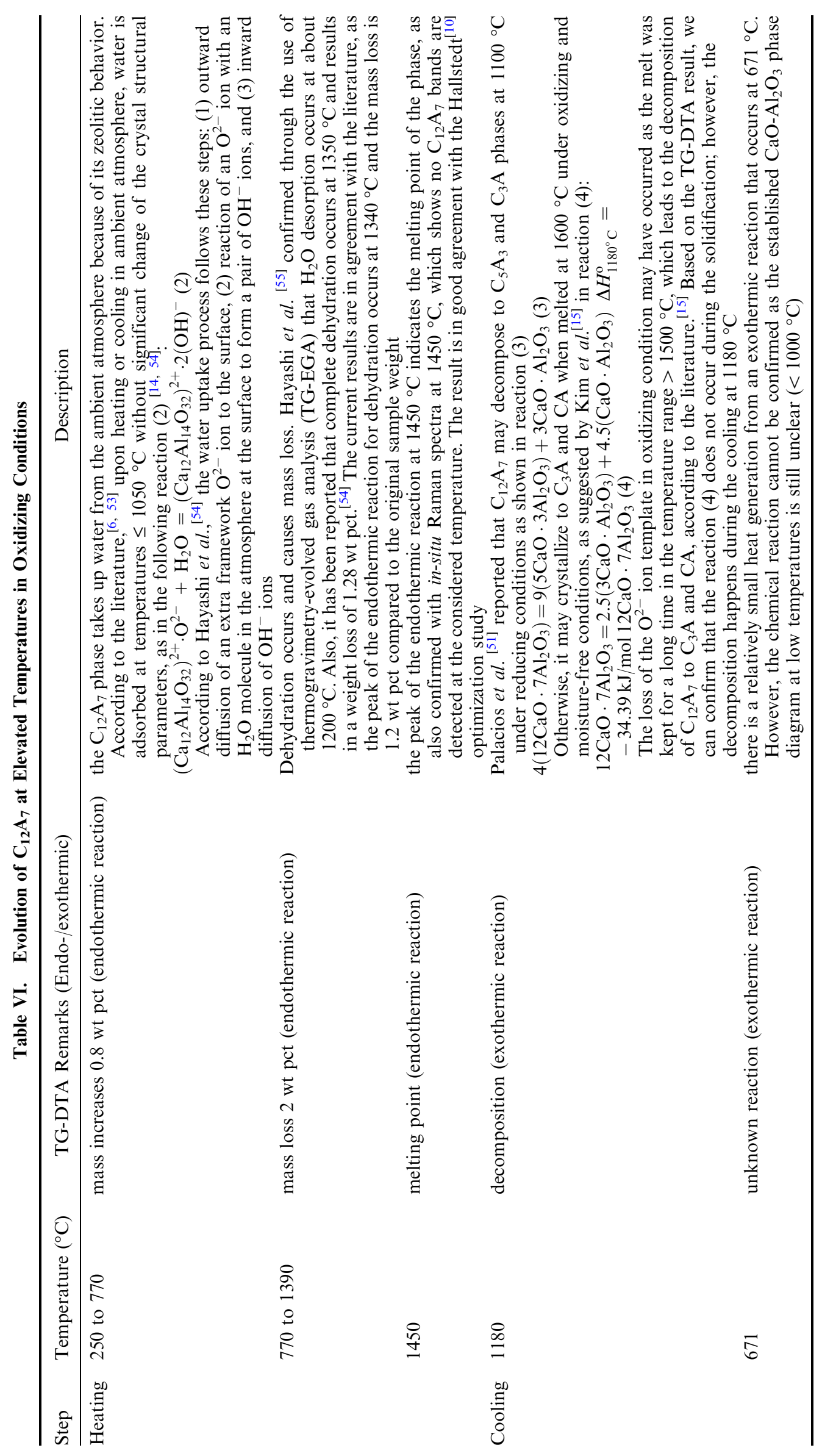




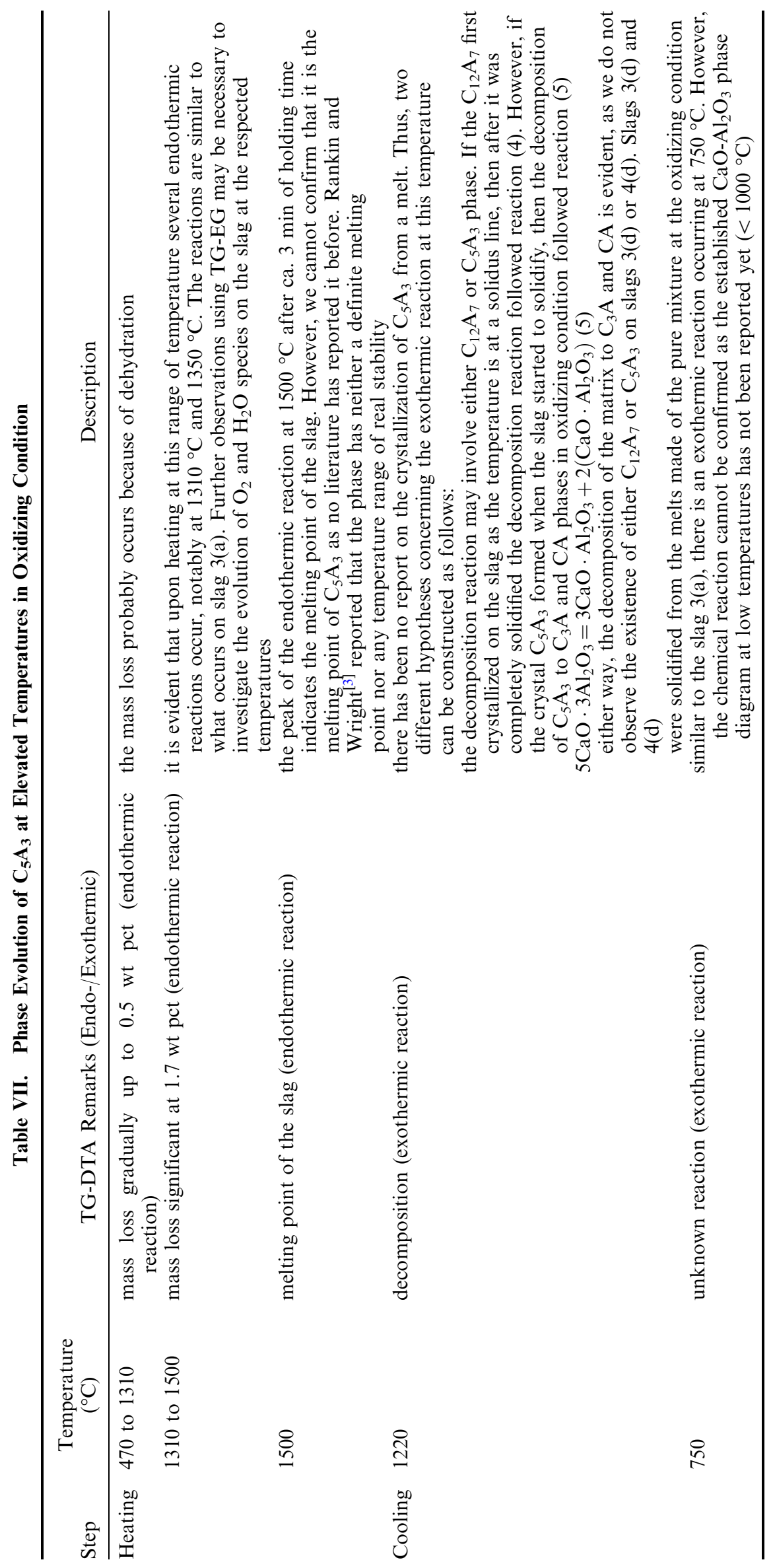




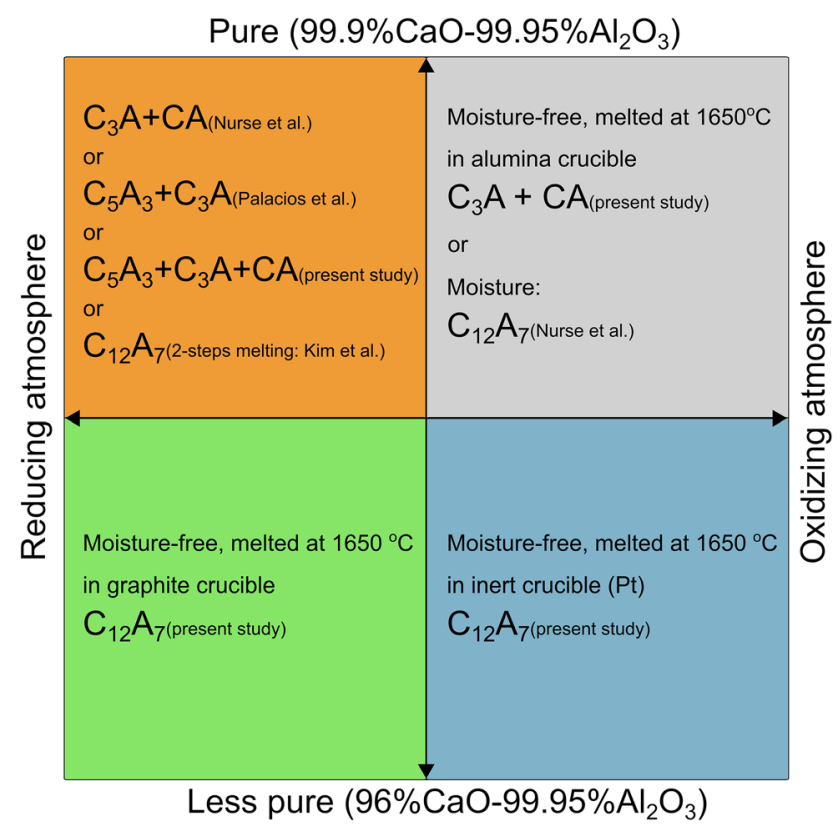

Fig. $21-$ Box chart of the stability of the $\mathrm{C}_{12} \mathrm{~A}_{7}$ phase in different atmospheric conditions and purities of the mixtures.

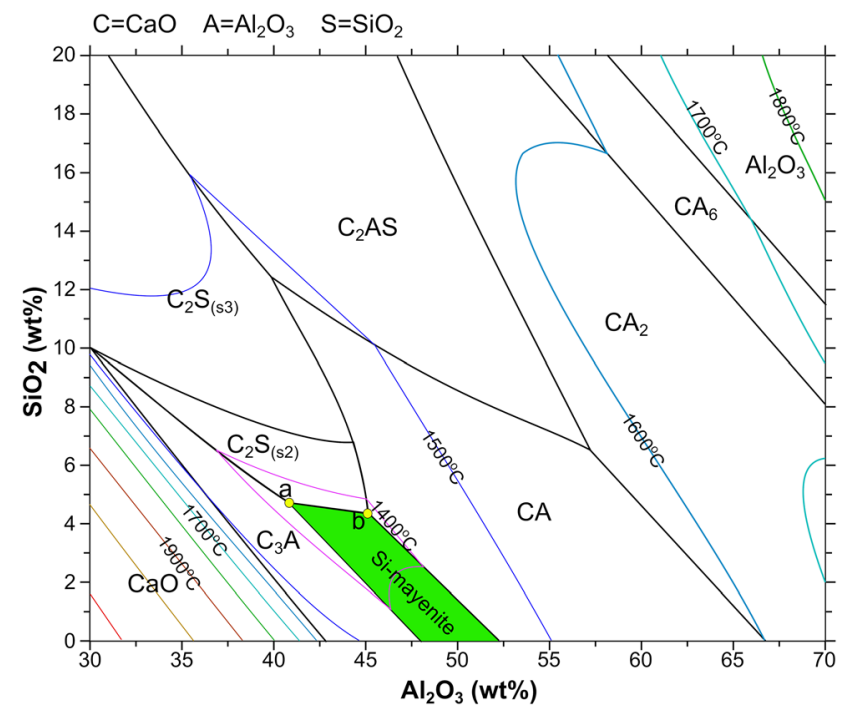

Fig. 22-Part of ternary $\mathrm{CaO}-\mathrm{Al}_{2} \mathrm{O}_{3}-\mathrm{SiO}_{2}$ phase diagram at low $\mathrm{SiO}_{2}$ mass fraction, which shows curve $\mathrm{a}-\mathrm{b}$ as the maximum solubility of $\mathrm{SiO}_{2}$ in Si-mayenite phase.

- The $5 \mathrm{CaO} \cdot 3 \mathrm{Al}_{2} \mathrm{O}_{3}$ phase is an unstable/intermediate phase in the ternary $\mathrm{CaO}-\mathrm{Al}_{2} \mathrm{O}_{3}-\mathrm{SiO}_{2}$ system. It is decomposed to $12 \mathrm{CaO} \cdot 7 \mathrm{Al}_{2} \mathrm{O}_{3}$ above $1100{ }^{\circ} \mathrm{C}$. However, in the current study, it exists only at room temperature when the $12 \mathrm{CaO} \cdot 7 \mathrm{Al}_{2} \mathrm{O}_{3}$ dissociates to a mixture of $5 \mathrm{CaO} \cdot 3 \mathrm{Al}_{2} \mathrm{O}_{3}, 3 \mathrm{CaO} \cdot \mathrm{Al}_{2} \mathrm{O}_{3}$, and $\mathrm{CaO} \cdot \mathrm{A}-$ $\mathrm{l}_{2} \mathrm{O}_{3}$ phases during the cooling of the slag at $1180{ }^{\circ} \mathrm{C}$ $\pm 20^{\circ} \mathrm{C}$ in a reducing atmosphere and is made from a pure 99.9 pet $\mathrm{CaO}$ to 99.95 pet $\mathrm{Al}_{2} \mathrm{O}_{3}$ mixture.

\section{ACKNOWLEDGMENTS}

This research has been partially funded by NTNU in association with the Research Domain 5-Materials and the Society in SFI Metal Production (Project No. 237738) and co-funded by the ENSUREAL EU project (Grant Agreement No. 767533). The support from both projects is acknowledged.

\section{CONFLICT OF INTEREST}

The authors declare that they have no known competing financial interests or personal relationships that could have appeared to influence the work reported in this paper.

\section{FUNDING}

Open Access funding provided by NTNU Norwegian University of Science and Technology (incl St. Olavs Hospital - Trondheim University Hospital)

\section{OPEN ACCESS}

This article is licensed under a Creative Commons Attribution 4.0 International License, which permits use, sharing, adaptation, distribution and reproduction in any medium or format, as long as you give appropriate credit to the original author(s) and the source, provide a link to the Creative Commons licence, and indicate if changes were made. The images or other third party material in this article are included in the article's Creative Commons licence, unless indicated otherwise in a credit line to the material. If material is not included in the article's Creative Commons licence and your intended use is not permitted by statutory regulation or exceeds the permitted use, you will need to obtain permission directly from the copyright holder. To view a copy of this licence, visit http://creativec ommons.org/licenses/by/4.0/.

\section{REFERENCES}

1. E.S. Shepherd, G.A. Rankin, and F.E. Wrigth: Am. J. Sci., 1909, vol. 28, pp. 293-33.

2. E.S. Shepherd and G.A. Rankin: J. Ind. Eng. Chem., 1911, vol. 3, pp. 211-27.

3. G.A. Rankin and F.E. Wright: Am. J. Sci., 1915, vol. 39, pp. 1-79.

4. W. Büssem and A. Eitel: Cryst. Mater., 1936, vol. 95, pp. 175-88.

5. R.W. Nurse, J.H. Welch, and A.J. Majumdar: Trans. Br. Ceram. Soc., 1965, vol. 64, pp. 409-18.

6. R.W. Nurse, J.H. Welch, and A.J. Majumdar: Trans. Br. Ceram. Soc., 1965, vol. 64, pp. 323-32.

7. D.M. Roy and R. Roy, 4th Int. Congr. Chem. Cem., 1960, 1, 307-14.

8. J.A. Imlach, L.S.D. Glasser, and F.P. Glasser: Cem. Concr. Res., 1971, vol. 1, pp. 57-61.

9. J. Jeevaratnam, L.S.D. Glasser, and F.P. Glasser: Nature, 1962, vol. 194, pp. 764-65.

10. B. Hallstedt: J. Am. Ceram. Soc., 1990, vol. 73, pp. 15-23.

11. D. Jerebtsov and G. Mikhailov: Ceram. Int., 2001, vol. 27, pp. 2528. 
12. G. Eriksson and A.D. Pelton: Metall. Trans. B., 1993, vol. 24, pp. 807-816.

13. E. Haccuria, T. Crivits, P.C. Hayes, and E. Jak: J. Am. Ceram. Soc., 2016, vol. 99, pp. 691-704.

14. R. Strandbakke, C. Kongshaug, R. Haugsrud, and T. Norby: $J$. Phys. Chem. C., 2009, vol. 113, pp. 8938-44.

15. S.W. Kim, Y. Toda, K. Hayashi, M. Hirano, and H. Hosono: Chem. Mater., 2006, vol. 18, pp. 1938-44.

16. L. Palacios, A. Cabeza, S. Bruque, S. García-Granda, and M.A.G. Aranda: Inorg. Chem., 2008, vol. 47, pp. 2661-67.

17. D. Jiang, Z. Zhao, S. Mu, V. Phaneuf, and J. Tong: Inorg. Chem., 2017, vol. 56, pp. 11702-09.

18. A. Schmidt, M. Lerch, J.-P. Eufinger, J. Janek, R. Dolle, H.-D. Wiemhöfer, I. Tranca, M.M. Islam, T. Bredow, H. Boysen, and M. Hoelzel: Solid State Sci., 2014, vol. 38, pp. 69-78.

19. S. Kim, M. Miyakawa, K. Hayashi, T. Sakai, M. Hirano, and H. Hosono: J. Am. Chem. Soc., 2005, vol. 127, pp. 1370-71.

20. S. Fujita, K. Suzuki, M. Ohkawa, T. Mori, Y. Iida, Y. Miwa, H. Masuda, and S. Shimada: Chem. Mater., 2003, vol. 15, pp. 255-63.

21. S.G. Ebbinghaus, H. Krause, D.-K. Lee, and J. Janek: Cryst. Growth Des., 2014, vol. 14, pp. 2240-45.

22. M.I. Bertoni, T.O. Mason, J.E. Medvedeva, A.J. Freeman, K.R. Poeppelmeier, and B. Delley: J. Appl. Phys., 2005, vol. 97, p. 103713.

23. S. Maurelli, M. Ruszak, S. Witkowski, P. Pietrzyk, M. Chiesa, and Z. Sojka: Phys. Chem. Chem. Phys., 2010, vol. 12, pp. 10933-41.

24. F.I. Azof, Y. Yang, D. Panias, L. Kolbeinsen, and J. Safarian: Hydrometallurgy, 2019, vol. 185, pp. 273-90.

25. F.I. Azof, L. Kolbeinsen, and J. Safarian, Proc. 35th Int. ICSOBA Conf., 2017, pp. 243-53.

26. A. Lazou, C. Van Der Eijk, E. Balomenos, and J. Safarian, Proc. Eur. Metallurgical Conf., 2019, pp. 17-34.

27. F.I. Azof, L. Kolbeinsen, and J. Safarian: Metall. Mater. Trans. B, 2018, vol. 49B, pp. 2400-20.

28. M.P. Vafeias, D. Marinos, D. Panias, J. Safarian, C. van Der Eijk, I. Solhem, E. Balomenos, M. Ksiazek, and Davris, Proc. 2nd Int. Bauxite Residue Valoris. Best Pract. Conf., 2018, pp. 111-17.

29. F.I. Azof, L. Kolbeinsen, and J. Safarian, Proc. Eur. Metall. Conf. 2019, pp. 511-26.

30. J. Safarian and L. Kolbeinsen: Ind. Process. Summit, 2016, vol. 5, pp. $149-58$.

31. J. Safarian and L. Kolbeinsen, Sustainability in Alumina Production from Bauxite, in: Sustain. Ind. Process. Summit, 2016: vol. 5, pp. $75-82$.

32. F.I. Azof, M. Vafeias, D. Panias, and J. Safarian: Hydrometallurgy, 2020, vol. 191, pp. 1-12.

33. O.C. Fursman, H.E. Blake Jr., and J.E. Mauser, US Department of the Interior, 1968, pp. 1-24.
34. H.E. Blake, O.C. Fursman, A.D. Fugate, and L.H. Banning, US Department of the Interior, 1966, pp. 1-21.

35. W. Bo, Z. Jianxin, Z. Shufeng, and S. Huilan, in: Light Metals, Grandfield J. (eds), 2014, pp. 87-90. Springer, Cham.

36. S. Graulis, D. Chateigner, R.T. Downs, A.F.T. Yokochi, M. Quirós, L. Lutterotti, E. Manakova, J. Butkus, P. Moeck, and A. Le Bail: J. Appl. Crystallogr., 2009, vol. 42, pp. 726-29.

37. S. Matsuishi, T. Nomura, M. Hirano, K. Kodama, S. Shamoto, and H. Hosono: Chem. Mater., 2009, vol. 21, pp. 2589-91.

38. M.G. Vincent and J.W. Jeffery: Acta Crystallogr., 1978, vol. 34, pp. $1422-28$

39. P. Mondal and J.W. Jeffery: Acta Crystallogr. B., 1975, vol. 31, pp. 689-97.

40. B. Lazić, V. Kahlenberg, J. Konzett, and R. Kaindl: Solid State Sci., 2006, vol. 8, pp. 589-97.

41. W. Hörkner and H. Müller-Buschbaum: J. Inorg. Nucl. Chem., 1976, vol. 38, pp. 983-84.

42. H.E. Swanson, H.F. McMurdie, M.C. Morris, and E.H. Evans: Natl. Bur. Stand., 1995, vol. 539, pp. 1-89.

43. W. Wong-Ng, H.F. McMurdie, B. Paretzkin, C.R. Hubbard, A.L. Dragoo, and J.M. Stewart: Powder Diffr., 1987, vol. 2, pp. 106-17.

44. E. Aruja: Acta Crystallogr., 1957, vol. 10, pp. 337-39.

45. P.J. Saines, M.M. Elcombe, and B.J. Kennedy: J. Solid State Chem., 2006, vol. 179, pp. 613-22.

46. P. McMillan and B. Piriou: J. Non. Cryst. Solids., 1983, vol. 55, pp. $221-42$.

47. A.G. Kokhman and G.I. Zhmoidin: Zhurnal Prikl. Spektrosk., 1981, vol. 35 , pp. $1322-26$.

48. P. Gillet: Phys. Chem. Miner., 1996, vol. 23, pp. 263-75.

49. A. Lazou, C. Van Der Eijk, E. Balomenos, L. Kolbeinsen, and J. Safarian: J. Sustain. Metall., 2020, vol. 6, pp. 227-38.

50. Cement Science, Buoyancy Effect of TGA Experiment (2013), h ttps://www.cementscience.com/2013/04/buoyancy-effect-of-tga-ex periment.html. Accessed on 22 August 2020.

51. L. Palacios, Á.G. De La Torre, S. Bruque, J.L. García-Muñoz, S. García-Granda, D. Sheptyakov, and M.A.G. Aranda: Inorg. Chem., 2007, vol. 46, pp. 4167-76.

52. G.I. Zhmoidin and A.K. Chatterjee: Cem. Concr. Res., 1984, vol. 14, pp. 386-96.

53. D.M. Roy and R. Roy, Fourth Int. Symp. Chem. Cem., 1960, pp. 307-314.

54. K. Hayashi, M. Hirano, and H. Hosono: J. Phys. Chem. B., 2005, vol. 109, pp. 11900-906.

55. K. Hayashi, M. Hirano, and H. Hosono: Chem. Lett., 2005, vol. 34 , pp. 586-87.

Publisher's Note Springer Nature remains neutral with regard to jurisdictional claims in published maps and institutional affiliations. 